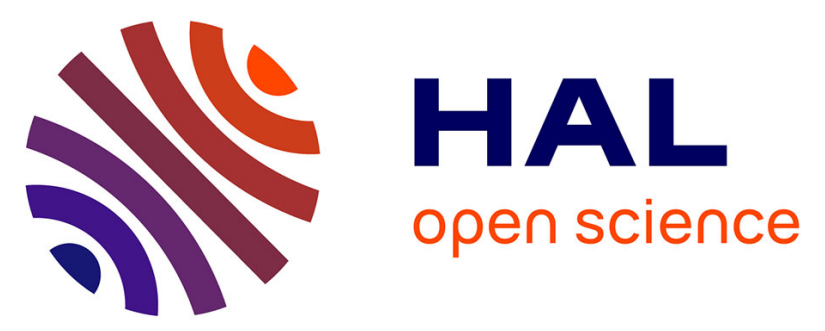

\title{
Highly enhanced oxidation of arsenite at the surface of birnessite in the presence of pyrophosphate and the underlying reaction mechanisms
}

Chaoyun Ying, Bruno Lanson, Cheng Wang, Xiaoming Wang, Hui Yin, Yupeng Yan, Wenfeng Tan, Fan Liu, Xionghan Feng

\section{To cite this version:}

Chaoyun Ying, Bruno Lanson, Cheng Wang, Xiaoming Wang, Hui Yin, et al.. Highly enhanced oxidation of arsenite at the surface of birnessite in the presence of pyrophosphate and the underlying reaction mechanisms. Water Research, 2020, 187, pp.116420. 10.1016/j.watres.2020.116420 . insu02984574

\section{HAL Id: insu-02984574 \\ https://hal-insu.archives-ouvertes.fr/insu-02984574}

Submitted on 24 Nov 2020

HAL is a multi-disciplinary open access archive for the deposit and dissemination of scientific research documents, whether they are published or not. The documents may come from teaching and research institutions in France or abroad, or from public or private research centers.
L'archive ouverte pluridisciplinaire HAL, est destinée au dépôt et à la diffusion de documents scientifiques de niveau recherche, publiés ou non, émanant des établissements d'enseignement et de recherche français ou étrangers, des laboratoires publics ou privés. 


\section{Highlights:}

- As(III) oxidation by birnessite leads to Mn(II/III) species formation

- Manganite precipitation passivates birnessite surface and limits As(III) oxidation

- Presence of pyrophosphate in reactive medium enhances As(III) oxidation

- PP inhibits passivation forming soluble $\mathrm{Mn}$ (III) complexes

- Oxidation enhancement by chelates depends on the stability of $\mathrm{Mn}$ (III) complexes 
Graphical Abstract

\section{Graphical Abstract}

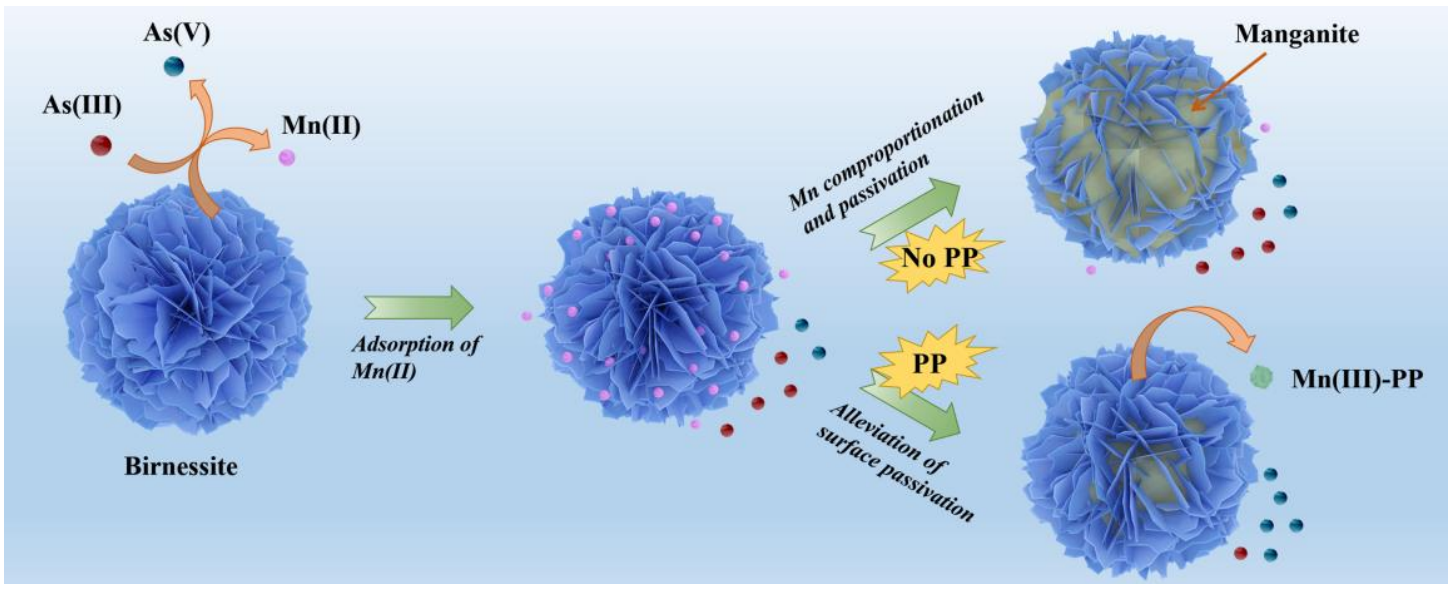


1 Highly enhanced oxidation of arsenite at the surface of birnessite in the presence

2 of pyrophosphate and the underlying reaction mechanisms

4 Chaoyun Ying ${ }^{a}$, Bruno Lanson ${ }^{b}$, Cheng Wang ${ }^{a}$, Xiaoming Wang ${ }^{a}$, Hui Yin ${ }^{a}$, Yupeng

5 Yan $^{a}$, Wenfeng Tan ${ }^{a}$, Fan Liu $^{a}$, Xionghan Feng ${ }^{a, *}$

6

$7 \quad{ }^{a}$ Key Laboratory of Arable Land Conservation (Middle and Lower Reaches of Yangtze

8 River), Ministry of Agriculture, College of Resources and Environment, Huazhong

9 Agricultural University, Wuhan 430070, China.

10 buniv. Grenoble Alpes, CNRS, Univ. Savoie Mont Blanc, IRD, Univ. Gustave Eiffel,

11 ISTerre, F-38000 Grenoble, France

$13 *$ Corresponding author:

14 Xionghan Feng,

15 Tel: +86 27 87280271; Fax: +86 27 87288618; E-mail: fxh73@ mail.hzau.edu.cn

18 Keywords: birnessite; arsenite oxidation; pyrophosphate; $M n(I I I)$ chelating;

19 depassivation 


\section{ABSTRACT}

Manganese(IV) oxides, and more especially birnessite, rank among the most efficient metal oxides for As(III) oxidation and subsequent sorption, and thus for arsenic immobilization. Efficiency is limited however by the precipitation of low valence Mn (hydr)oxides at the birnessite surface that leads to its passivation. The present work investigates experimentally the influence of chelating agents on this oxidative process. Specifically, the influence of sodium pyrophosphate (PP), an efficient Mn(III) chelating agent, on As(III) oxidation by birnessite was investigated using batch experiments and different arsenic concentrations at circum-neutral $\mathrm{pH}$. In the absence of $\mathrm{PP}, \mathrm{Mn}(\mathrm{II} / \mathrm{III})$ species are continuously generated during $\mathrm{As}(\mathrm{III})$ oxidation and adsorbed to the mineral surface. Field emission-scanning electron microscopy, synchrotron-based X-ray diffraction and Fourier transform infrared spectroscopy indicate that manganite is formed, passivating birnessite surface and thus hampering the oxidative process. In the presence of PP, generated $\mathrm{Mn}(\mathrm{II} / \mathrm{III})$ species form soluble complexes, thus inhibiting surface passivation and promoting As(III) conversion to As(V) from $60 \%$ in the absence of PP to $100 \%$ with $3 \mathrm{mM}$ PP (0.5 mM initial As(III)). Enhancement of As(III) oxidation by Mn oxides strongly depends on the affinity of the chelating agent for $\mathrm{Mn}(\mathrm{III})$ and from the induced stability of $\mathrm{Mn}(\mathrm{III})$ complexes. Compared to PP, the positive influence of oxalate, for example, on the oxidative process is more limited. The present study thus provides new insights into the possible optimization of arsenic removal from water using $\mathrm{Mn}$ oxides, and on the possible environmental control of arsenic contamination by these 
ubiquitous non-toxic mineral species.

\section{Introduction}

In natural waters, arsenite, As(III), mainly occurs as the neutral species $\mathrm{H}_{3} \mathrm{AsO}_{3}$, while arsenate, $\mathrm{As}(\mathrm{V})$, is present as $\mathrm{H}_{2} \mathrm{AsO}_{4}{ }^{-}$or $\mathrm{HAsO}_{4}{ }^{2-}$ oxyanions under a variety of pH conditions (Cerkez et al., 2015). Both forms are highly toxic and carcinogenic, and the maximum contaminant level for arsenic in drinking water defined by the World Health Organization (WHO) is thus extremely low at $10 \mu \mathrm{g} / \mathrm{L}$. Arsenite is even more toxic and mobile than arsenate in aqueous environments (Cerkez et al., 2015; Fischel et al., 2015; Neppolian et al., 2010) and more difficult to remove owing to its low affinity for sorbents (Luong et al., 2018). Oxidizing As(III) into the more easily extractable $\mathrm{As}(\mathrm{V})$ thus appears appropriate to achieve efficient arsenic immobilization and removal (Zhang et al., 2016).

Although As(III) is stable in homogeneous systems (Katsoyiannis and Zouboulis, 2004; Tsang et al., 2007), a variety of metal oxides such as iron (hydr)oxides (Amirbahman et al., 2006; Wang and Giammar, 2015; Yang et al., 2017; Zhao et al., 2011) and titanium oxides (Dutta et al., 2004; Ferguson et al., 2005; Guan et al., 2012) can induce its oxidation directly or indirectly. As a consequence, As concentration in natural aqueous environments is essentially controlled by interactions with mineral surfaces. Composite oxides have also been developed to enhance their efficiency as oxidants and adsorbents for both As(III) and As(V) (Chakravarty et al., 2002; Feng et al., 2006a; Ma et al., 2020; McCann et al., 2018; Wu et al., 2018; Ying et al., 2012; 
Zhang et al., 2007; Zhang et al., 2018; Zheng et al., 2020). Manganese (Mn) oxides can also oxidize As(III) (Manning et al., 2002; Scott and Morgan, 1995), as reported in natural lacustrine environments (Oscarson et al., 1980, 1981a, 1981b), and Mn oxides have a key role in As geochemical cycling (Driehaus et al., 1995; Nesbitt et al., 1998; Scott and Morgan, 1995; Tournassat et al., 2002). Produced Mn(II) adsorbs to the particle edges, thus potentially blocking reactive sites for further oxidation (Villalobos et al., 2014). Lafferty and coworkers (Lafferty et al., 2010a, 2010b, 2011) identified $\mathrm{Mn}(\mathrm{II})$ as the unique reduced product during the initial phase of the reaction. They also concluded that $\mathrm{Mn}(\mathrm{III})$ was subsequently formed as the result of the comproportionation of $\mathrm{Mn}(\mathrm{II})$ adsorbed onto birnessite surface rather than from $\mathrm{Mn}(\mathrm{IV})$ reduction, as previously hypothesized (Nesbitt et al., 1998). Manganite $(\gamma-\mathrm{Mn}(\mathrm{III}) \mathrm{OOH})$ then accumulates at the birnessite surface leading to its passivation, as $\mathrm{Mn}(\mathrm{III})$ sites are less reactive than $\mathrm{Mn}(\mathrm{IV})$ ones with respect to As(III) oxidation, as shown by DFT calculations (Zhu et al., 2009). Finally, Lafferty and coworkers showed that $\mathrm{As}(\mathrm{V})$ was the sole As species adsorbed to manganese oxides (Lafferty et al., 2010a, 2010b, 2011).

In contrast to the optimization of the oxidizing solid, little attention has been paid to the influence of additional chemicals present in the reactive medium. For example, the presence of phosphate in solution hampers As(III) oxidation by Mn oxides (Chiu and Hering, 2000; Parikh et al., 2010), whereas that of tartaric acid promotes it (Feng et al., 2006b). More generally, the presence in the reactive medium of compounds chelating $\mathrm{Mn}$, and more especially $\mathrm{Mn}(\mathrm{III})$, is expected to enhance the oxidative 
process (Ma et al., 2020). With this respect, pyrophosphate (PP) appears especially relevant owing to its strong affinity for Mn(III) (Liu et al., 2019; Marafatto et al., 2018; Parker et al., 2004; Soldatova et al., 2017). The relevance of PP is further

91 increased by its common formation in natural environments, as the simplest polymer 92 of orthophosphate resulting from the breakdown of ATP and ADP (Klewicki and 93 Morgan, 1999b; Trouwborst et al., 2006).

The present experimental work thus investigated in detail the influence of PP on As(III) oxidation by the Mn oxide birnessite at circumneutral $\mathrm{pH}$. The effect of PP addition on the completeness of the reaction and the involved reaction mechanisms were specifically studied from a combination of wet chemical analyses and of solid phase characterization using electron microscopy, X-ray diffraction, X-ray absorption and photoelectron spectroscopies, and infrared spectroscopy.

\section{Materials and Methods}

\subsection{Chemicals}

All chemical used in the present study were purchased from Sinopharm

104 Chemical Reagent, except for the manganese(III) acetate dihydrate which was

105 purchased from Sigma Chemical. All chemicals were of analytical grade. Atomic

106 absorption spectroscopy Mn standard was prepared by dilution of a $1000 \mathrm{mg} / \mathrm{L}$

107 standard. Deionized water was used throughout the experiments. 
Synthetic acid birnessite was prepared according to a method modified from that

111 of McKenzie (1971). In brief, $45 \mathrm{~mL}$ of a $6 \mathrm{M} \mathrm{HCl}$ solution were added dropwise to 300

$112 \mathrm{~mL}$ of a boiling $0.667 \mathrm{M}$ solution of $\mathrm{KMnO}_{4}$. The obtained suspension was stored at

$11360^{\circ} \mathrm{C}$ for $12 \mathrm{~h}$ to increase birnessite crystallinity. Resulting solid was then washed with

114 deionized water and centrifuged $(10 \times)$ to remove $\mathrm{K}^{+}$and $\mathrm{Cl}^{-}$in excess.

\subsection{Batch As(III) Oxidation by Birnessite and Wet Chemical Analyses}

Batch experiments were conducted using $50 \mathrm{~mL}$ of a $0.2 \mathrm{~g} / \mathrm{L}$ suspension of the

118 obtained synthetic birnessite at two As(III) concentrations $(0.5$ and $1 \mathrm{mM})$ in the

119 presence/absence of sodium pyrophosphate (PP). When present, PP concentrations

120 were $1,2,3,4,5,8$, and $10 \mathrm{mM}$, with a $2.5 \mathrm{mM} \mathrm{NaCl}$ background electrolyte. Mixed

121 suspensions, whose $\mathrm{pH}$ was pre-adjusted to 7.2 using $0.2-1 \mathrm{mM} \mathrm{HCl}$, were then

122 stirred for $24 \mathrm{~h}$. The solids were subsequently filtered and washed thoroughly with

123 deionized water to remove residual dissolved ions.

124 In the absence of PP, As(V) was determined using the ammonium molybdenum

125 method (Oscarson et al., 1980). In the presence of PP, As(III) and As(V) were

126 determined using coupled LC-ICP-MS, As(III) and As(V) being separated by liquid

127 chromatography (LC - Dionex IonPac AS19 Columns) using a four-component 128 mobile phase $(\mathrm{pH} 10.22)$ at $1 \mathrm{~mL} / \mathrm{min}$ flow rate. The outflow from the LC was 129 directly connected to the inductively coupled plasma mass spectrometer (ICP-MS) for 
130 As quantification. In specific experiments, PP was replaced by other chelating agents,

131 such as sodium oxalate. In this case, $\mathrm{As}(\mathrm{V})$ and total As concentrations were measured

132 using the molybdenum blue method (Feng et al., 2018), the concentration of As(III)

133 being calculated from that of total As by subtracting As(V).

134 Mn concentration in solution was determined using atomic absorption

135 spectrometry (AAS - Agilent Technologies 200 series). In addition, concentration of

$136 \mathrm{Mn}(\mathrm{III})$-PP complexes were determined with a UV-Vis spectrophotometer (Agilent

137 Technologies Cary 8454), using $10 \mathrm{~mm}$ path length cuvettes and the absorption peaks

138 at $258 \mathrm{~nm}$ and $480 \mathrm{~nm}$ (Webb et al., 2005).

139

\subsection{Characterization of the Solid Products.}

$141 \quad$ 2.4.1 Mn K-edge XANES and Mn speciation analysis

X-ray absorption near edge structure (XANES) spectroscopy data were collected

143 at room temperature on the 1W1B beamline at the Beijing Synchrotron Radiation

144 Facility (BSRF) over the 6.4-7.0 keV range (Mn K-edge). Energy calibration was

145 systematically performed using a Mn metal foil before data collection. Mn K-edge

146 spectra were averaged and background-subtracted using the following parameters:

$147 \mathrm{E}_{0}=6538 \mathrm{eV}, \mathrm{Rbkg}=1 \AA$ and $\mathrm{k}$-weight $=2$. 
151 microscope (FESEM - SU8010, Hitachi) with a maximum resolution of $1 \mathrm{~nm}$. For 152 high-resolution images, the microscope was operated at $10 \mathrm{kV}$ using a working 153 distance of 10-15 mm, and an in-lens secondary electron detector.

157 BL14B1 beamline of the Shanghai Synchrotron Radiation Facility (SSRF). Data were

158 collected over the $2-45^{\circ} 2 \theta$ range $(\lambda=0.6895 \AA$ ), with 30 s exposure times (Yang et al., 159 2015).

160

163 with a deuterated triglycine sulfate detector (Bruker Optics Inc., Ettlingen, Germany).

164 Spectra were measured over the $4000-400 \mathrm{~cm}^{-1}$ range with a $4 \mathrm{~cm}^{-1}$ resolution in 165 transmission mode. Thirty-two scans were collected and averaged for each sample, the 166 data being collected, processed, and analyzed with the OPUS program. 
X-ray photoelectron spectra (XPS) were collected using a VG Multilab2000 X-ray

170 photoelectron spectrometer with an $\mathrm{Al} \mathrm{K} \mathrm{X-ray} \mathrm{source}(1486 \mathrm{eV})$ and a base pressure

171 of $3 \times 10^{-9}$ Torr in the analytical chamber. The scans were recorded using the large area

172 mode. The survey scans were collected using a fixed pass energy of $100 \mathrm{eV}$ and an

173 energy step size of $1.0 \mathrm{eV}$, whereas the narrow scans have a pass energy of $25 \mathrm{eV}$ and

174 an energy step size of $0.1 \mathrm{eV}$. Spectra were charge-corrected to $\mathrm{C} 1 s$ with a binding 175 energy of $284.80 \mathrm{eV}$ collected from the surface adventitious carbon (Wang et al., 2010)

176 and analyzed with the Avantage software. The parameters proposed by Ilton et al. 177 (2016) and Bang et al. (2005) for the spectral fitting of Mn3p and As3d multiple peaks 178 were used.

\section{Results and Discussion}

\subsection{The Oxidation of As(III) by Birnessite with/without Chelating Agents}

Based on their relative redox potentials, As(III) could be oxidized by dissolved oxygen under circum-neutral conditions $\left(\triangle \mathrm{E}\right.$ for $\mathrm{O}_{2} / \mathrm{H}_{2} \mathrm{O}$ and $\mathrm{As}(\mathrm{V}) / \mathrm{As}(\mathrm{III})$ couples is $0.70 \mathrm{~V}$ at neutral $\mathrm{pH}$ ). However, As(III) is mostly hydrophilic and present as neutral (Lan et al., 2018). Consistently, the control experiments performed in the absence of 

able to oxidize $\sim 35 \%$ of the As(III) initially present $(1 \mathrm{mM})$ to $\mathrm{As}(\mathrm{V})$ after $24 \mathrm{~h}$ (Fig.

191 1a), whereas $\sim 10 \%$ of As adsorbed/precipitated at the birnessite surface. The As(III)

192 concentration dropped exponentially with time over the first $2 \mathrm{~h}$. The application of a 193 pseudo-first order model yielded an apparent As(III) oxidation rate constant $(k)$ of $1940.1804 \pm 0.0349 \mathrm{~h}^{-1}\left(k_{l}\right)$ over this $2 \mathrm{~h}$ interval (Fig. 1b). The reaction slowed down 195 over the subsequent $10 \mathrm{~h}$ with an apparent rate constant decreased by about one order 196 of magnitude $\left(k_{2}=0.0187 \pm 0.0015 \mathrm{~h}^{-1}\right)$, most likely as the result of the formation of a 197 Mn precipitate passivating birnessite surface (Lafferty et al., 2010a). After 12 h, As(III) 198 was not oxidized by birnessite anymore, consistent with the following equations 199 proposed for As(III) oxidation (Lafferty et al., 2010a, 2010b):

$>\mathrm{Mn}(\mathrm{IV})-\mathrm{OH}+\mathrm{H}_{3} \mathrm{As}(\mathrm{III}) \mathrm{O}_{3}+\mathrm{H}^{+} \rightarrow \mathrm{Mn}(\mathrm{II})+\mathrm{H}_{2} \mathrm{As}(\mathrm{V}) \mathrm{O}_{4}{ }^{-}+\mathrm{H}_{2} \mathrm{O}$

$>\mathrm{Mn}(\mathrm{IV})-\mathrm{OH}+\mathrm{Mn}(\mathrm{II})+\mathrm{H}_{2} \mathrm{O}+\mathrm{H}^{+} \rightarrow 2\left(>\mathrm{Mn}(\mathrm{III})-\mathrm{OH}_{2}\right)$ process, the formation of $\mathrm{Mn}(\mathrm{III})$ resulting from the comproportionation of 206 surface-adsorbed $\mathrm{Mn}(\mathrm{II})$ and structural $\mathrm{Mn}(\mathrm{IV})$ (Eq. 2). The proportion of As(III) 207 oxidized by birnessite over $24 \mathrm{~h}$ was doubled in the presence of $5 \mathrm{mM}$ PP in solution 208 compared to the PP-free system (Fig. 1a). In the presence of PP, As(III) oxidation was 209 not significantly promoted over the first 2 hours, the apparent rate constant being $2100.1993 \pm 0.0125 \mathrm{~h}^{-1}\left(k_{3}\right.$, compared to $k_{1}=0.1804 \pm 0.0349 \mathrm{~h}^{-1}-$ Fig. $\left.1 \mathrm{~b}\right)$. Over the next 
21110 hours, As(III) oxidation was highly enhanced in the presence of $5 \mathrm{mM} \mathrm{PP}$, however,

212 with an apparent rate constant of $0.0438 \pm 0.0101 \mathrm{~h}^{-1}\left(k_{4}\right)$. Moreover, addition of PP

213 allowed releasing to solution As species initially adsorbed/precipitated at the

214 birnessite surface (Fig. 1a). Enhancement of As(III) oxidation results from the

215 chelation by PP of $\mathrm{Mn}(\mathrm{III})$ formed as the result of Eq. 2 and from the release of these

216 complexes to solution (Eq. 3 - Klewicki and Morgan, 1999b):

Previous works showed that the excess of PP relative to $\mathrm{Mn}(\mathrm{III})$ should be at

222 least fourfold to prevent the complexes from disproportionating (Qian et al., 2019).

223 Thus, the difference between $k_{4}$ and the oxidation rate determined over the subsequent

22412 hours $\left(k_{5}=0.0091 \pm 0.0025 \mathrm{~h}^{-1}\right)$ is likely related to the formation of $\mathrm{Mn}$ (III) that 225 could not be fully chelated by PP (Fig. 1b).

226 Mn concentration in solution increased steadily in the presence of PP (Fig. 2a), 227 nevertheless, as shown by the increase in intensity of the $258 \mathrm{~nm}$ UV-Vis absorption 228 band (Fig. 2b) that is characteristic of the Mn(III)-PP complex (Soldatova et al., 2017).

229 Consistently, the filtered solution appeared brownish red (Fig. S2), a color typical for 230 Mn(III)-PP (Qian et al., 2019). High-valent Mn in solution, which hereafter refers to 231 Mn(III)-PP, was quantified using Leucoberbelin Blue I (Zhu et al., 2017). The similar 232 increases of aqueous $\mathrm{Mn}$ and of $\mathrm{Mn}(\mathrm{III})-\mathrm{PP}$ indicated that $\mathrm{Mn}$ in solution was 
overwhelmingly trivalent and present as Mn(III)-PP (Fig. 2a), consistent with XANES

234 results (Fig. S3). In the presence of both $\mathrm{As}(\mathrm{III})$ and $\mathrm{As}(\mathrm{V}), \mathrm{Mn}(\mathrm{III})-\mathrm{PP}$ complexes

235 remained essentially stable over a $24 \mathrm{~h}$ interval in circum-neutral conditions (Table S1

236 and Fig. S4), consistent with the slow disproportionation reported for $\mathrm{Mn}(\mathrm{III})-\mathrm{PP}$ at

237 circum-neutral pH (Qian et al., 2019). The minor decrease of Mn(III)-PP after $12 \mathrm{~h}$ is

238 possibly related to Mn oxides catalyzing PP hydrolysis (Wan et al., 2019).

239 The premise from Eq. 3 was supported by the experimental ratio between As(V),

240 produced from Eq. 1, aqueous Mn(III), produced from Eq. 2 and complexed by PP,

241 that steadily approached a 1:2 ratio with increasing PP in the presence of $0.5 \mathrm{mM}$

242 As(III) (Fig. S5), consistent with the stoichiometric ratio from Eqs. 1, 2. At low PP

243 concentration, the experimental ratio was significantly larger than $1: 2$ due to the

244 limited formation of Mn(III)-PP complexes. Increasing PP concentrations increased

$245 \mathrm{Mn}(\mathrm{III})-\mathrm{PP}$ concentration in solution, birnessite being essentially dissolved over $24 \mathrm{~h}$

246 in the presence of $10 \mathrm{mM}$ PP and $1 \mathrm{mM} \mathrm{As(III)} \mathrm{(Fig.} \mathrm{3).} \mathrm{The} \mathrm{stoichiometric} \mathrm{1:2} \mathrm{ratio}$

247 between $\mathrm{As}(\mathrm{V})$ and $\mathrm{Mn}$ indicates that the oxidation of $1 \mathrm{mM} \mathrm{As}(\mathrm{III})$ required the

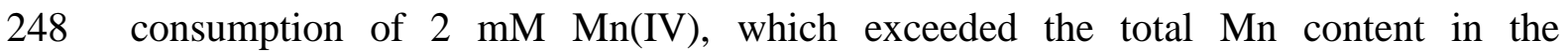

249 suspension. As a result, $\mathrm{As}(\mathrm{V})$ in solution never reached $1 \mathrm{mM}$ even in the presence of

$25010 \mathrm{mM}$ PP.

251 In addition, time-resolved As K-edge XANES spectroscopy was used to 252 determine the overall relative proportions of $\mathrm{As}(\mathrm{III})$ and $\mathrm{As}(\mathrm{V})$ in the reaction system 253 (Fig. S6). The position of As $\mathrm{K}$ absorption edge steadily shifted to higher energies 254 with increasing reaction time, showing the formation of $\mathrm{As}(\mathrm{V})$ at the expense of 
255 As(III). Linear combination fitting (LCF) of the spectra unraveled the in-situ 256 evolution kinetics of As(III) and As(V) species. The kinetic of As(III) oxidation using 257 pseudo-first order model was linear over the first $180 \mathrm{~min}$ in the presence of PP 258 (apparent rate constant $k=0.0049 \pm 0.0001 \mathrm{~h}^{-1}-$ Fig. S7) and of the induced 259 alleviation of surface passivation.

\subsection{Identification of the Solid Products}

Birnessite synthesized in the present study exhibited a uniform nano-flower morphology resulting from the assemblage of nano-flakes as revealed by FESEM (Fig.

264 4). When reacted with $\mathrm{As}(\mathrm{III})$ in the absence of PP, these nano-flowers appeared 265 "filled" after $24 \mathrm{~h}$ of reaction, nano-flake edges becoming blurred, owing to the 266 presence of precipitates at the particle surface. Increasing PP concentration in solution 267 appeared to prevent the presence of these precipitates, leaving clean birnessite 268 surfaces and thus significantly alleviating the passivation of birnessite surface.

SR-XRD patterns of the unreacted birnessite exhibited reflections at 0.723 (not

270 shown), 0.361, 0.244, and $0.142 \mathrm{~nm}$ typical for birnessite (Fig. 5a). After reacting 271 with $1 \mathrm{mM} \mathrm{As(III)}$ for $24 \mathrm{~h}$ in the absence of PP, additional reflections typical for 272 manganite (ICDD\#41-1379) were visible (Fig. 5a). Manganite precipitation was 273 consistent with previous reports of birnessite interactions with aqueous $\mathrm{Mn}$ (II) at 274 circum-neutral pH (Elzinga, 2011; Lefkowitz et al., 2013; Tournassat et al., 2002). 275 Manganite peaks were not visible when PP was present in the reacting suspension, 
276 however (Fig. 5a). None of the various manganese arsenate compounds with 277 contrasting As: Mn molar ratios reported in the literature as secondary products of 278 As(III) oxidation by birnessite (Moore et al., 1990; Tournassat et al., 2002) were

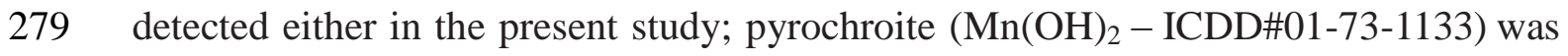
280 not observed either.

281 The $920 \mathrm{~cm}^{-1}$ band in the FT-IR spectrum of unreacted birnessite corresponded to 282 the bending vibration of -OH located at vacancy sites (Fig. 5b - Yin et al., 2017; Zhao 283 et al., 2012). After reaction with As(III) for $24 \mathrm{~h}$ in the absence of PP, new bands were 284 visible at 1150,1116 , and $1087 \mathrm{~cm}^{-1}$ that were related to in-plane and out-of-plane 285 bending modes of structural $\mathrm{OH}$ in manganite (Kohler et al., 1997; Lefkowitz et al., 286 2013), consistent with the presence of this phase shown by XRD data. Consistent with 287 XRD data, these bands, typical for manganite, were not visible when PP was added to 288 the reactive system.

289 In addition, XPS allowed identifying the chemical state of elements in the few 290 uppermost atomic layers of solids and monitoring the evolution of Mn oxidation state at 291 the birnessite surface. Mn3p XPS spectra were fitted using scale factors for the three 292 multiplets used (Table S2) (Ilton et al., 2016), and the relative contributions of the 293 different Mn oxidation states were quantified from the overall multiplet area (Fig. 6) 294 (Table 1). The best fit to Mn3p spectrum of unreacted birnessite yielded 67\% Mn(IV), $29529 \% \mathrm{Mn}(\mathrm{III})$, and $4 \% \mathrm{Mn}(\mathrm{II})$, and the relative proportion of $\mathrm{Mn}(\mathrm{IV})$ at birnessite 296 surface decreasing to $41 \%$ after reaction with $\mathrm{As}(\mathrm{III})$ in the absence of PP. 297 Simultaneously, $\mathrm{Mn}(\mathrm{III})$ and $\mathrm{Mn}(\mathrm{II})$ increased to $50 \%$ and $9 \%$, respectively, as the 
result of As(III) oxidation. The significant increase of $\mathrm{Mn}(\mathrm{III})$ was consistent with the key role played by $\mathrm{Mn}(\mathrm{IV})$ in the oxidation of As(III) and with the observed formation

300 of manganite at the particle surface (Figs. 4, 5). If PP was added to the reactive system,

301 the relative content of $\mathrm{Mn}(\mathrm{III})$ at the birnessite particle surface decreased (Table 1), 302 consistent with increased proportion of $\mathrm{Mn}$ (III)-PP in solution and the absence of 303 manganite formation. Enhancement of As(III) oxidation thus appeared to be induced by 304 the absence of birnessite surface passivation, resulting from manganite precipitation, 305 which was caused by Mn(III) complexation by PP. This enhancement was consistent 306 with theoretical calculations showing the higher affinity of both As(III) and As(V) for $307 \mathrm{Mn}(\mathrm{IV})$ sites compared to $\mathrm{Mn}(\mathrm{III})$ sites and with the increased electron transfer rate 308 between $\mathrm{As}(\mathrm{III})$ and $\mathrm{Mn}(\mathrm{IV})$, compared to Mn(III) (Zhu et al., 2009). Finally, XPS 309 As3d spectra were characteristic of coexisting As(V) and As(III) species (Fig. S8), 310 whose binding energies were $45.5 \pm 0.1 \mathrm{eV}$ and $44.2 \pm 0.1 \mathrm{eV}$, respectively (Table S3 311 - Bang et al., 2005). In the absence of PP, adsorbed/precipitated As was essentially 312 present as As(V), consistent with previous reports (Fig. S8 - Lafferty et al., 2010b).

\subsection{The Effects of Different Chelating Agents on As(III) Oxidation}

Naturally occurring organic ligands other than PP, such as oxalate and citrate, are

316 also known to chelate Mn (Duckworth and Sposito, 2005; Jiang et al., 2019; Klewicki 317 and Morgan, 1999a; Mu et al., 2018; Taube, 1947; Zhang et al., 2019). As for PP, the 318 presence of oxalate in the reactive system promoted As(III) oxidation (by $\sim 15 \%$ after 
320 leucoberbelin blue dye (Zhu et al., 2017), however. The limited enhancement of As(III)

321 oxidation by oxalate was most likely linked to the reduced release of $\mathrm{Mn}$ (III) in

322 solution, and thus to the lower ability of oxalate, compared to PP, to prevent surface

323 passivation by chelating $\mathrm{Mn}$ (III) formed during the reaction (Eqs. 1, 2; Fig. 7b). The

324 lower chelating activity of oxalate, compared to PP, was consistent with the respective

325 stability constants of these complexing agents with $\mathrm{Mn}(\mathrm{III})(\log K$ are 9.98 and 11.7

326 for oxalate and PP, respectively) (Nico and Zasoski, 2001). Consistently, the

327 first-order rate constant determined for the breakdown of $\mathrm{Mn}$ (III)-oxalate complexes

$328\left(\mathrm{Mn}(\mathrm{III})\left(\mathrm{C}_{2} \mathrm{O}_{4}\right)^{+}, k=1.97 \times 10^{-1} \mathrm{~s}^{-1}\right)$ was six orders of magnitude higher than that of

$329 \mathrm{Mn}(\mathrm{III})-\mathrm{PP}\left(\mathrm{Mn}(\mathrm{III}) \mathrm{HP}_{2} \mathrm{O}_{5}, k=3 \times 10^{-7} \mathrm{~s}^{-1}\right)$ under neutral conditions (Nicholson and

330 Eley, 1997; Taube, 1947; Zhang et al., 2019). Moreover, organic ligands, such as

331 oxalate, are considered as reducing agents interacting with Mn (hydr)oxides (Flynn

332 and Catalano, 2019; Wang et al., 2018; Wang and Stone, 2006). Therefore, the ligands

333 with both low reducing ability (or no redox activity) and high complexation ability

334 with Mn(III), such as PP (Klewicki and Morgan, 1998), appear as ideal inhibitors of

$335 \mathrm{Mn}(\mathrm{III})$ (hydr)oxide formation during reaction with As(III).

\subsection{Environmental significance}

338 Birnessite is ubiquitous in aquatic and terrestrial environments (Butterfield et al., 339 2013), where As(III) potentially coexists with pyrophosphate (PP). The major source 
340 of PP in the environment appears to be ATP released from cells that can be hydrolyzed

341 quickly to produce PP (Orriss et al., 2016). The above results provide a mechanistic

342 understanding for the enhancement of As(III) oxidation by birnessite in the presence

343 of PP through alleviation of surface passivation when the three species coexist.

344 As As(III) oxidation to As(V) is an effective pathway for arsenic detoxification

345 in arsenic-containing drinking and waste water, birnessite is a potentially attractive

346 oxidant to be used in large-scale treatment. Previous studies have shown that the

347 presence of aqueous $\mathrm{Fe}(\mathrm{II})$ and $\mathrm{Mn}(\mathrm{II})$ may inhibit As(III) oxidation by birnessite

348 (Gude et al., 2017), however, as these species are oxidized at the birnessite surface

349 leading to its passivation and favoring As(III) (Ehlert et al., 2014). In the presence of

350 PP, precipitation of $\mathrm{Mn}(\mathrm{III})$ on the surface of birnessite will likely be removed, thus

351 alleviating surface passivation and enhancing As(III) oxidation. Hydrous ferric oxides,

352 such as ferrihydrite (Ehlert et al., 2014), formed at the birnessite surface are also

353 likely to be dissolved in the presence of PP (Kassim et al., 1984), thus releasing

354 adsorbed As(III) to solution and promoting its oxidative interaction with birnessite.

356 4. Conclusions

As previously reported, oxidation of $\mathrm{As}(\mathrm{III})$ in presence of birnessite and at 358 circum-neutral $\mathrm{pH}$ conditions proceeds as a two-electron transfer. The subsequent 359 formation of $\mathrm{Mn}$ (III) results from the comproportionation of $\mathrm{Mn}$ (II) and $\mathrm{Mn}(\mathrm{IV})$ and 360 leads to the precipitation of manganite at the surface of the initial birnessite particles. 
361 Manganite precipitation passivates birnessite surface and restrains As(III) oxidation

362 completeness. In the presence of PP, As(III) oxidation is significantly enhanced at

363 circum-neutral $\mathrm{pH}$. The major influence of PP on As(III) oxidation results from its

364 strong chelating affinity for $\mathrm{Mn}(\mathrm{III})$, causing the relative content of $\mathrm{Mn}(\mathrm{III})$ at the

365 birnessite surface to decrease. PP chelates newly formed $\mathrm{Mn}(\mathrm{III})$ and thus inhibits the

366 formation of solid $\mathrm{Mn}(\mathrm{III})$ phases, such as manganite, that may passivate birnessite

367 surface. The addition of PP to the oxidative system has major implications both for

368 the efficiency of As(III) removal during water treatment and for the durability of

369 birnessite as oxidizing catalyzer. Compared to other $\mathrm{Mn}(\mathrm{III})$ chelating agents, such as

370 oxalate, pyrophosphate appears especially efficient in impeding surface passivation

371 and limiting possible reductive activity.

373 Declaration of interest statement

374 Declarations of interest: none.

376 Acknowledgments

377 This work was supported by National Key R\&D Program of China (No.

378 2017YFD0200201), and the National Natural Science Foundation of China (NSFC

379 Grant Nos. 41471194). 


\section{Appendix. Supporting Information}

\section{References}

Amirbahman, A., Kent, D.B., Curtis, G.P. and Davis, J.A. 2006. Kinetics of sorption and abiotic oxidation of arsenic(III) by aquifer materials. Geochim. Cosmochim. Acta 70, 533-547.

Bang, S., Johnson, M.D., Korfiatis, G.P. and Meng, X. 2005. Chemical reactions between arsenic and zero-valent iron in water. Water Res. 39(5), 763-770.

Butterfield, C.N., Soldatova, A.V., Lee, S.W., Spiro, T.G. and Tebo, B.M. 2013. Mn(II,III) oxidation and $\mathrm{MnO}_{2}$ mineralization by an expressed bacterial multicopper oxidase. Proc. Natl. Acad. Sci. U. S. A. 110(29), 11731-11735.

Cerkez, E.B., Bhandari, N., Reeder, R.J. and Strongin, D.R. 2015. Coupled redox transformation of chromate and arsenite on ferrihydrite. Environ. Sci. Technol. 49(5), 2858-2866.

Chakravarty, S., Dureja, V., Bhattacharyya, G., Maity, S. and Bhattacharjee, S. 2002. Removal of arsenic from groundwater using low cost ferruginous manganese ore. Water Res. 36, 625-632.

Chiu, V.Q. and Hering, J.G. 2000. Arsenic adsorption and oxidation at manganite surfaces. 1. Method for simultaneous determination of adsorbed and dissolved arsenic species. Environ. Sci. Technol. 34, 2029-2034.

Driehaus, W., Seith, R. and Jekel, M. 1995. Oxidation of arsenate(III) with manganese oxides in water treatment. Water Res. 29, 297-305.

Duckworth, O.W. and Sposito, G. 2005. Siderophore-manganese(III) interactions. I. Air-oxidation of manganese(1l) promoted by desferrioxamine B. Environ. Sci. Technol. 39(16), 6037-6044.

Dutta, P.K., Ray, A.K., Sharma, V.K. and Millero, F.J. 2004. Adsorption of arsenate and arsenite on titanium dioxide suspensions. J. Colloid Interface Sci. 278(2), 270-275.

Ehlert, K., Mikutta, C. and Kretzschmar, R. 2014. Impact of birnessite on arsenic and iron speciation during microbial reduction of arsenic-bearing ferrihydrite. Environ. Sci. Technol 48(19), 11320-11329.

Elzinga, E.J. 2011. Reductive transformation of birnessite by aqueous Mn(II). Environ. Sci. Technol. 45(15), 6366-6372.

Feng, X., Tan, W., Liu, F., Ruan, H.D. and He, J. 2006a. Oxidation of As ${ }^{\text {III }}$ by several manganese oxide minerals in absence and presence of goethite. Acta Geol. Sin. 80(2), 249-256.

Feng, X., Wang, P., Shi, Z., Kwon, K.D., Zhao, H., Yin, H., Lin, Z., Zhu, M., Liang, X., Liu, F. and Sparks, D.L. 2018. A quantitative model for the coupled kinetics of arsenic adsorption/desorption and oxidation on manganese oxides. Environ. Sci. Technol Letter 5, $175-180$.

Feng, X., Zu, Y., Tan, W. and Liu, F. 2006b. Arsenite oxidation by three types of manganese oxides. J. Environ. Sci. 18(2), 292-298.

Ferguson, M.A., Hoffmann, M.R. and Hering, J.G. 2005. TiO2-photocatalyzed As (III) oxidation in 
aqueous suspensions: reaction kinetics and effects of adsorption. Environ. Sci. Technol. 39(6), 1880-1886.

Fischel, M.H.H., Fischel, J.S., Lafferty, B.J. and Sparks, D.L. 2015. The influence of environmental conditions on kinetics of arsenite oxidation by manganese-oxides. Geochem. Trans. 16(15).

Flynn, E.D. and Catalano, J.G. 2019. Reductive transformations of layered manganese oxides by small organic acids and the fate of trace metals. Geochim. Cosmochim. Acta 250, 149-172.

Guan, X., Du, J., Meng, X., Sun, Y., Sun, B. and Hu, Q. 2012. Application of titanium dioxide in arsenic removal from water: a review. J. Hazard. Mater. 215, 1-16.

Gude, J.C.J., Rietveld, L.C. and van Halem, D. 2017. As(III) oxidation by $\mathrm{MnO}_{2}$ during groundwater treatment. Water Res. 111, 41-51.

Harrington, J.M., Parker, D.L., Bargar, J.R., Jarzecki, A.A., Tebo, B.M., Sposito, G. and Duckworth, O.W. 2012. Structural dependence of Mn complexation by siderophores: Donor group dependence on complex stability and reactivity. Geochimica et Cosmochimica Acta 88, 106-119.

Ilton, E.S., Post, J.E., Heaney, P.J., Ling, F.T. and Kerisit, S.N. 2016. XPS determination of Mn oxidation states in Mn (hydr)oxides. Appl. Surf. Sci. 366, 475-485.

Jiang, B., Gong, Y., Gao, J., Sun, T., Liu, Y., Oturan, N. and Oturan, M.A. 2019. The reduction of Cr(VI) to $\mathrm{Cr}(\mathrm{III})$ mediated by environmentally relevant carboxylic acids: State-of-the-art and perspectives. J. Hazard. Mater. 365, 205-226.

Kassim, J., Gafoor, S. and Adams, W. 1984. Ferrihydrite in pyrophosphate extracts of podzol B horizons. Clay Miner. 19(1), 99-106.

Katsoyiannis, I.A. and Zouboulis, A.I. 2004. Application of biological processes for the removal of arsenic from groundwaters. Water Res. 38(1), 17-26.

Klewicki, J.K. and Morgan, J.J. 1998. Kinetic Behavior of Mn(III) Complexes of Pyrophosphate, EDTA, and Citrate. Environ. Sci. Technol 32, 2916-2922.

Klewicki, J.K. and Morgan, J.J. 1999a. Dissolution of $\beta-\mathrm{MnOOH}$ particles by ligands Pyrophosphate, ethylenediaminetetraacetate, and citrate. Geochim. Cosmochim. Acta 63, 3017-3024.

Klewicki, J.K. and Morgan, J.J. 1999b. Dissolution of $\beta-\mathrm{MnOOH}$ particles by ligands: Pyrophosphate, ethylenediaminetetraacetate, and citrate. Geochim. Cosmochim. Acta 63(19/20), 3017-3024.

Kohler, T., Armbruster, T. and Libowitzky, E. 1997. Hydrogen bonding and Jahn-Teller distortion in groutite, $\alpha-\mathrm{MnOOH}$, and manganite, $\gamma \mathrm{MnOOH}$, and their relations to the manganese dioxides ramsdellite and pyrolusite. J. Solid State Chem. 133, 486-500.

Lafferty, B.J., Ginder-Vogel, M. and Sparks, D.L. 2011. Arsenite oxidation by a poorly-crystalline manganese oxide. 3. Arsenic and manganese desorption. Environ. Sci. Technol. 45(21), 9218-9223.

Lafferty, B.J., Ginder-Voger, M. and Sparks, D.L. 2010a. Arsenite oxidation by a poorly crystalline manganese-oxide 1. Stirred-flow experiments. Environ. Sci. Technol. 44(22), 8460-8466.

Lafferty, B.J., Ginder-Voger, M., Zhu, M., Livi, K.J.T. and Sparks, D.L. 2010b. Arsenite oxidation by a poorly crystalline manganese-oxide. 2 . Results from X-ray absorption spectroscopy and X-ray diffraction. Environ. Sci. Technol. 44(22), 8467-8472.

Lan, S., Ying, H., Wang, X., Liu, F., Tan, W., Huang, Q., Zhang, J. and Feng, X. 2018. Efficient catalytic As(III) oxidation on the surface of ferrihydrite in the presence of aqueous Mn(II). Water Res. $128,92-101$.

Lefkowitz, J.P., Rouff, A.A. and Elzinga, E.J. 2013. Influence of pH on the reductive transformation of 
birnessite by aqueous Mn(II). Environ. Sci. Technol. 47(18), 10364-10371.

Liu, W., Sun, B., Qiao, J. and Guan, X. 2019. Influence of pyrophosphate on the generation of soluble Mn(III) from reactions involving Mn oxides and Mn(VII). Environ. Sci. Technol. 53(17), 10227-10235.

Luong, V.T., Kurz, E.E.C., Hellriegel, U., Luu, T.L., Hoinkis, J. and Bundschuh, J. 2018. Iron-based subsurface arsenic removal technologies by aeration: a review of the current state and future prospects. Water Res. 133, 110-122.

Luther, G.W., Ruppel, D.T. and Burkhard, C. (1998), ACS Publications.

Ma, L., Cai, D. and Tu, S. 2020. Arsenite simultaneous sorption and oxidation by natural ferruginous manganese ores with various ratios of Mn/Fe. Chem. Eng. J. 382, 123040.

Manning, B.A., Fendorf, S.E., Bostick, B. and Suarez, D.L. 2002. Arsenic (III) oxidation and arsenic (V) adsorption reactions on synthetic birnessite. Environ. Sci. Technol. 36(5), 976-981.

Marafatto, F.F., Lanson, B. and Peña, J. 2018. Crystal growth and aggregation in suspensions of $\delta$-MnO2 nanoparticles: implications for surface reactivity. Environ. Sci. Nano 5(2), 497-508.

McCann, C.M., Peacock, C.L., Hudson-Edwards, K.A., Shrimpton, T., Gray, N.D. and Johnson, K.L. 2018. In situ arsenic oxidation and sorption by a Fe-Mn binary oxide waste in soil. J. Hazard. Mater. 342, 724-731.

McKenzie, R.M. 1971. The synthesis of birnessite, cryptomelane, and some other oxides and hydroxides of manganese. Miner. Mag. 38, 493-502.

Moore, J.N., Walker, J.R. and Hayes, T.H. 1990. Reaction scheme for the oxidation of As(III) to As(V) by birnessite. Clay. Clay Miner. 38(5), 549-555.

Mu, Y., Jiang, X., Ai, Z., Jia, F. and Zhang, L. 2018. $\mathrm{Mn}^{2+}$ promoted Cr(VI) reduction with oxalic acid: The indispensable role of In-situ generated $\mathrm{Mn}^{3+}$. J. Hazard. Mater. 343, 356-363.

Neppolian, B., Doronila, A. and Ashokkumar, M. 2010. Sonochemical oxidation of arsenic(III) to arsenic(V) using potassium peroxydisulfate as an oxidizing agent. Water Res. 44(12), 3687-3695.

Nesbitt, H.W., Canning, G.W. and Bancroft, G.M. 1998. XPS study of reductive dissolution of $7 \AA$ A-birnessite by $\mathrm{H}_{3} \mathrm{AsO}_{3}$, with constraints on reaction mechanism. Geochim. Cosmochim. Acta 62(12), 2097-2110.

Nicholson, K. and Eley, M. 1997. Geochemistry of manganese oxides: metal adsorption in freshwater and marine environments. Geological Society London Special Publications 119(1), 309-326.

Nico, P.S. and Zasoski, R.J. 2001. Mn(III) center availability as a rate controlling factor in the oxidation of phenol and sulfide on $\delta-\mathrm{MnO}_{2}$. Environ. Sci. Technol. 35, 3338-3343.

Orriss, I.R., Arnett, T.R. and Russell, R.G. 2016. Pyrophosphate: a key inhibitor of mineralisation. Curr Opin Pharmacol 28, 57-68.

Oscarson, D.W., Huang, P.M., Defosse, C. and Herbillon, A. 1981a. Oxidative power of Mn(IV) and $\mathrm{Fe}(\mathrm{III})$ oxides with respect As(III) in terrestrial and aquatic envrionments. Nature 291, 50-51.

Oscarson, D.W., Huang, P.M. and Liaw, W.K. 1980. The oxidation of arsenite by aquatic sediments. J. Environ. Qual. 9, 700-703.

Oscarson, D.W., Huang, P.M. and Liaw, W.K. 1981b. Role of manganese in the oxidation of arsenite by freshwater lake sediments. Clay. Clay Miner. 29(3), 219-225.

Parikh, S.J., Lafferty, B.J., Meade, T.G. and Sparks, D.L. 2010. Evaluating environmental influences on As ${ }^{\text {III }}$ oxidation kinetics by a poorly crystalline Mn-oxide. Environ. Sci. Technol. 44, 3772-3778.

Parker, D.L., Sposito, G. and Tebo, B.M. 2004. Manganese (III) binding to a pyoverdine siderophore 
produced by a manganese (II)-oxidizing bacterium. Geochim. Cosmochim. Acta 68(23), 4809-4820.

Qian, A., Zhang, W., Shi, C., Pan, C., Giammar, D.E., Yuan, S., Zhang, H. and Wang, Z. 2019. Geochemical stability of dissolved Mn(III) in the presence of pyrophosphate as a model ligand: complexation and disproportionation. Environ. Sci. Technol. 53(10), 5768-5777.

Scott, M.J. and Morgan, J.J. 1995. Reactions at oxide surfaces. 1. Oxidation of As(lll) by synthetic birnessite. Environ. Sci. Technol. 29(8), 1898-1905.

Soldatova, A.V., Romano, C.A., Tao, L., Stich, T.A., Casey, W.H., Britt, R.D., Tebo, B.M. and Spiro, T.G. 2017. Mn(II) oxidation by the multicopper oxidase complex Mnx: A coordinated two-stage Mn(II)/(III) and Mn(III)/(IV) mechanism. J. Am. Chem. Soc. 139(33), 11381-11391.

Taube, H. 1947. Catalysis of the reaction of chlorine and oxalic acid. Complexes of trivalent manganese in solutions containing oxalic acid. J. Am. Chem. Soc. 69(6), 1418-1428.

Tournassat, C., Chalet, L., Bosbach, D. and Manceau, A. 2002. Arsenic(III) oxidation by birnessite and precipitation of manganese(II) arsenate. Environ. Sci. Technol. (36), 493-500.

Trouwborst, R.E., Clement, B.G., Tebo, B.M., Glazer, B.T. and Luther, G.W., 3rd 2006. Soluble Mn(III) in suboxic zones. Science 313(5795), 1955-1957.

Tsang, S., Phu, F., Baum, M.M. and Poskrebyshev, G.A. 2007. Determination of phosphate/arsenate by a modified molybdenum blue method and reduction of arsenate by $\mathrm{S}(2) \mathrm{O}(4)(2-)$. Talanta 71(4), 1560-1568.

Villalobos, M., Escobar-Quiroz, I.N. and Salazar-Camacho, C. 2014. The influence of particle size and structure on the sorption and oxidation behavior of birnessite: I. Adsorption of $\mathrm{As}(\mathrm{V})$ and oxidation of As(III). Geochim. Cosmochim. Acta 125, 564-581.

Wan, B., Huang, R., Diaz, J.M. and Tang, Y. 2019. Manganese Oxide Catalyzed Hydrolysis of Polyphosphates. ACS Earth Space Chem. 3(11), 2623-2634.

Wang, L. and Giammar, D.E. 2015. Effects of pH, dissolved oxygen, and aqueous ferrous iron on the adsorption of arsenic to lepidocrocite. J. Colloid Interface Sci. 448, 331-338.

Wang, Q., Yang, P. and Zhu, M. 2018. Structural transformation of birnessite by fulvic acid under anoxic conditions. Environ. Sci. Technol. 52(4), 1844-1853.

Wang, Y. and Stone, A.T. 2006. Reaction of $\mathrm{Mn}^{\text {IIIIV }}$ (hydr)oxides with oxalic acid, glyoxylic acid, phosphonoformic acid, and structurally-related organic compounds. Geochim. Cosmochim. Acta 70(17), 4477-4490.

Wang, Z., Lv, K., Wang, G., Deng, K. and Tang, D. 2010. Study on the shape control and photocatalytic activity of high-energy anatase titania. Appl. Catal. B 100(1-2), 378-385.

Webb, S.M., Dick, G.J., Bargar, J.R. and Tebo, B.M. 2005. Evidence for the presence of Mn(III) intermediates in the bacterial oxidation of Mn(II). Proc. Natl. Acad. Sci. U S A 102(15), 5558-5563.

Wu, Y., Kukkadapu, R.K., Livi, K.J.T., Xu, W., Li, W. and Sparks, D.L. 2018. Iron and arsenic speciation during As(III) oxidation by manganese oxides in the presence of $\mathrm{Fe}(\mathrm{II})$ : Molecular-level characterization using XAFS, Mössbauer, and TEM analysis. ACS Earth Space Chem. 2(3), 256-268.

Yang, T., Wen, W., Yin, G. and Gao, X. 2015. Introduction of the X-ray diffraction beamline. Nucl. Sci. Tech. 26(2), 020101.

Yang, X., Xia, L., Li, J., Dai, M., Yang, G. and Song, S. 2017. Adsorption of As (III) on porous hematite synthesized from goethite concentrate. Chemosphere 169, 188-193. 
Yin, H., Kwon, K.D., Lee, J.-Y., Shen, Y., Zhao, H., Wang, X., Liu, F., Zhang, J. and Feng, X. 2017. Distinct effects of $\mathrm{Al}^{3+}$ doping on the structure and properties of hexagonal turbostratic birnessite: A comparison with Fe3+ doping. Geochim. Cosmochim. Acta 208, 268-284.

Ying, S.C., Kocar, B.D. and Fendorf, S. 2012. Oxidation and competitive retention of arsenic between iron- and manganese oxides. Geochim. Cosmochim. Acta 96, 294-303.

Zhang, C., Liao, X., Lü, Y. and Nan, C. 2019. Enhanced degradation of methyl parathion in the ligand stabilized soluble Mn(III)-sulfite system. J. Earth Sci. 30, 861-869.

Zhang, G., Qu, J., Liu, H., Liu, R. and Guo, T. 2007. Removal mechanism of As(III) by a novel Fe-Mn binary oxide adsorbent: Oxidation and sorption. Environ. Sci. Technol. 41, 4613-4619.

Zhang, L., Zhu, T., Liu, X. and Zhang, W. 2016. Simultaneous oxidation and adsorption of As (III) from water by cerium modified chitosan ultrafine nanobiosorbent. J. Hazard. Mater. 308, 1-10.

Zhang, W., Zhang, G., Liu, C., Li, J., Zheng, T., Ma, J., Wang, L., Jiang, J. and Zhai, X. 2018. Enhanced removal of arsenite and arsenate by a multifunctional Fe-Ti-Mn composite oxide: photooxidation, oxidation and adsorption. Water Res. 147, 264-275.

Zhao, W., Liu, F., Feng, X., Tan, W., Qiu, G. and Chen, X. 2012. Fourier transform infrared spectroscopy study of acid birnessites before and after $\mathrm{Pb}^{2+}$ adsorption. Clay Miner. 47(02), 191-204.

Zhao, Z., Jia, Y., Xu, L. and Zhao, S. 2011. Adsorption and heterogeneous oxidation of As (III) on ferrihydrite. Water Res. 45(19), 6496-6504.

Zheng, Q., Hou, J., Hartley, W., Ren, L., Wang, M., Tu, S. and Tan, W. 2020. As(III) adsorption on Fe-Mn binary oxides: Are Fe and Mn oxides synergistic or antagonistic for arsenic removal? Chem. Eng. J. 389, 124470.

Zhu, M., Paul, K.W., Kubicki, J.D. and Sparks, D.L. 2009. Quantum chemical study of arsenic (III, V) adsorption on Mn-oxides, implications for arsenic(III) oxidation. Environ. Sci. Technol. 43, 6655-6661.

Zhu, Y., Liang, X., Zhao, H., Yin, H., Liu, M., Liu, F. and Feng, X. 2017. Rapid determination of the Mn average oxidation state of Mn oxides with a novel two-step colorimetric method. Anal. Methods 9(1), 103-109.

\section{Legends of figures and tables}

Fig. 1 (a) Evolution of As(III), As(V), and total As concentrations in solution during As(III) oxidation by birnessite in the absence/presence of $5 \mathrm{mM}$ PP (1.0 mM initial As(III) concentration, initial pH 7.2, 24 h). (b) Kinetic analysis of As(III) removal using pseudo-first order model.

Fig. 2 (a) Evolution of aqueous Mn species concentrations in solution during As(III) oxidation by birnessite in the absence/presence of $5 \mathrm{mM}$ PP (1.0 mM initial As(III) 
UV-Vis absorption spectra of the solutions containing Mn(III)-PP as the result of As(III) oxidation experiments (dilution in 1:5 in deionized water) in the presence of birnessite and PP (5 mM PP, $1.0 \mathrm{mM}$ initial As(III) concentration, initial pH 7.2).

Fig. $3 \mathrm{As}(\mathrm{III}), \mathrm{As}(\mathrm{V})$, and Mn concentrations in solution and the ratio between $\mathrm{Mn}$ and $591 \mathrm{As}(\mathrm{V})$ as a function of the pyrophosphate (PP) concentration for As(III) oxidation 592 experiments in the presence of birnessite (1.0 mM initial As(III) concentration, initial $593 \mathrm{pH} \mathrm{7.2,24} \mathrm{h).}$

594 Fig. 4 FESEM images of unreacted synthetic birnessite (Bir) and of reaction products 595 from As(III) oxidation experiments in the presence of birnessite (1.0 mM initial As(III) 596 concentration, initial $\mathrm{pH} 7.2,24 \mathrm{~h})$. 0mM: absence of pyrophosphate (PP); $2 \mathrm{mM}$ : 597 initial PP concentration $2 \mathrm{mM}$; 5mM: initial PP concentration $5 \mathrm{mM}$.

598 Fig. 5 (a) XRD patterns and (b) FT-IR spectra of unreacted birnessite (Bir) and of 599 solid reaction products from As(III) oxidation experiments in the presence of 600 birnessite (1.0 mM initial As(III) concentration, initial pH 7.2, $24 \mathrm{~h}) .0 \mathrm{mM}, 2 \mathrm{mM}$, and $6015 \mathrm{mM}$ labels as in Fig. 4. Ticks at the bottom of (a) indicate the position of manganite 602 reflections (ICDD\#41-1379).

603 Fig. 6 XPS spectra (Mn3p) of unreacted birnessite (Bir) and of solid reaction products 604 from As(III) oxidation experiments in the presence of birnessite (1.0 mM initial As(III) 605 concentration, initial pH 7.2, 24 h). 0mM, 2mM, and 5mM labels as in Fig. 4.

606 Fig. 7 Evolution of (a) As(III), As(V), and total As concentrations, and of (b) aqueous 607 Mn species concentrations during As(III) oxidation by birnessite in the 
608 absence/presence of $5 \mathrm{mM}$ oxalate (1.0 mM initial As(III) concentration, initial $\mathrm{pH}$ $609 \quad 7.2,24$ h).

610 Table 1 Relative proportions of the different Mn oxidation states at the birnessite 611 surface determined from the fits of Mn3p XPS spectra shown in Fig. 6. 


\section{Tables}

Table 1

Relative proportions of the different Mn oxidation states determined from the fits of Mn3p XPS spectra shown in Fig. 6.

\begin{tabular}{|c|c|c|c|c|}
\hline \multirow{2}{*}{ Samples } & \multicolumn{4}{|c|}{$\operatorname{Mn}($ At.\%) } \\
\hline & $\mathrm{Mn}(\mathrm{IV})$ & $\mathrm{Mn}(\mathrm{III})$ & $\mathrm{Mn}(\mathrm{II})$ & AOS \\
\hline Bir & 67 & 29 & 4 & 3.63 \\
\hline $\begin{array}{c}0 \mathrm{mM} \text { PP } \\
1 \mathrm{mM} \mathrm{As}(\mathrm{III})\end{array}$ & 41 & 50 & 9 & 3.32 \\
\hline $\begin{array}{c}2 \mathrm{mM} \text { PP } \\
1 \mathrm{mM} \mathrm{As}(\mathrm{III})\end{array}$ & 46 & 42 & 12 & 3.34 \\
\hline $\begin{array}{c}5 \mathrm{mM} \text { PP } \\
1 \mathrm{mM} \mathrm{As}(\mathrm{III})\end{array}$ & 49 & 38 & 13 & 3.35 \\
\hline
\end{tabular}



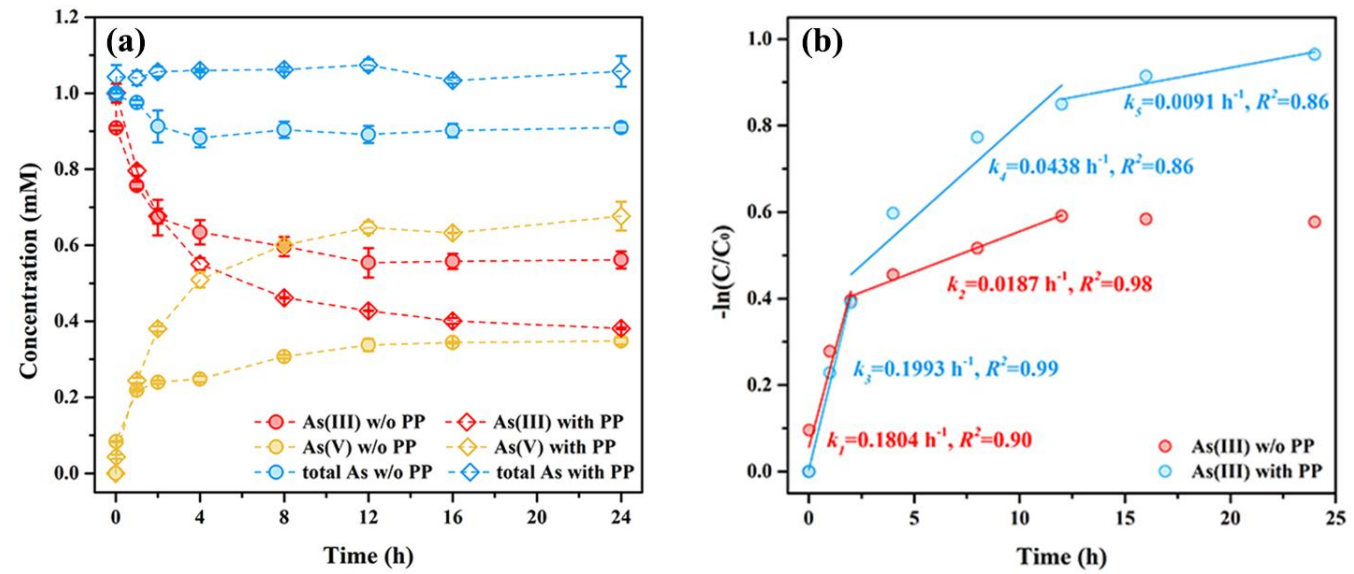

Fig. 1 (a) Evolution of As(III), As(V), and total As concentrations in solution during As(III) oxidation by birnessite in the absence/presence of $5 \mathrm{mM}$ PP (1.0 mM initial As(III) concentration, initial pH 7.2, 24 h). (b) Kinetic analysis of As(III) removal using pseudo-first order model. 

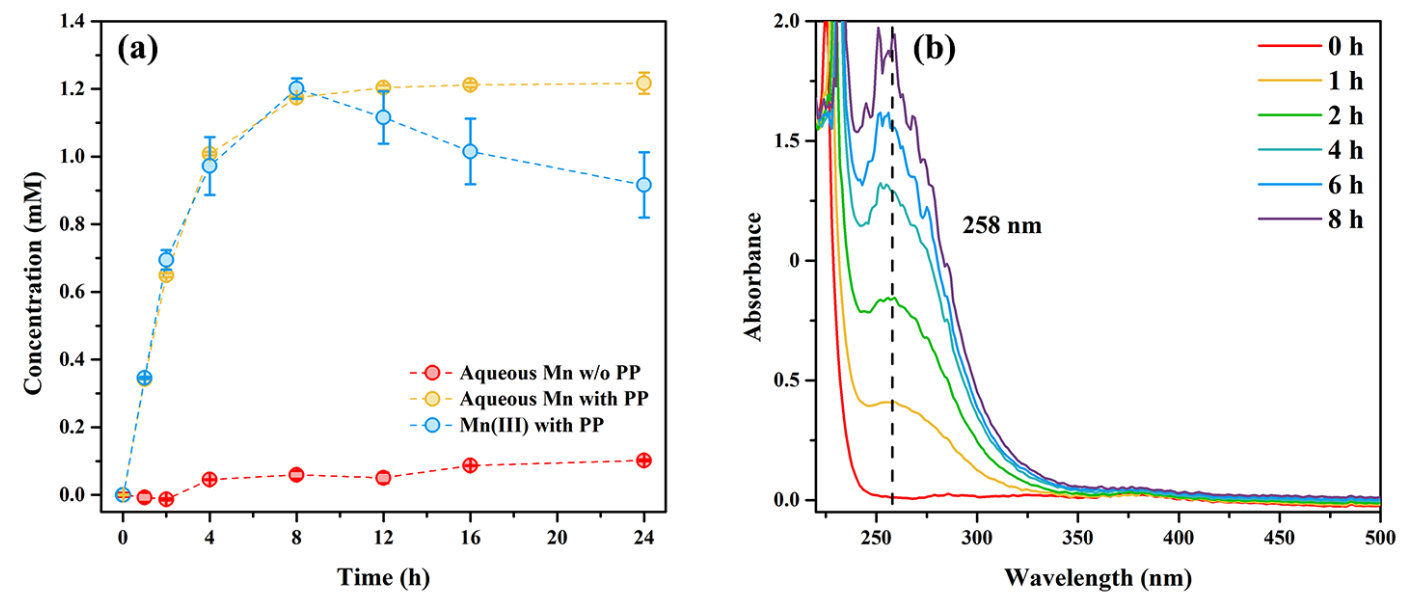

Fig. 2 (a) Evolution of aqueous Mn species concentrations in solution during As(III) oxidation by birnessite in the absence/presence of $5 \mathrm{mM}$ PP (1.0 $\mathrm{mM}$ initial As(III) concentration, initial $\mathrm{pH} 7.2,24 \mathrm{~h}$ ). (b) Evolution as a function of reaction time of UV-Vis absorption spectra of the solutions containing $\mathrm{Mn}(\mathrm{III})-\mathrm{PP}$ as the result of As(III) oxidation experiments (dilution in 1:5 in deionized water) in the presence of birnessite and PP (5 mM PP, $1.0 \mathrm{mM}$ initial As(III) concentration, initial $\mathrm{pH}$ 7.2). 


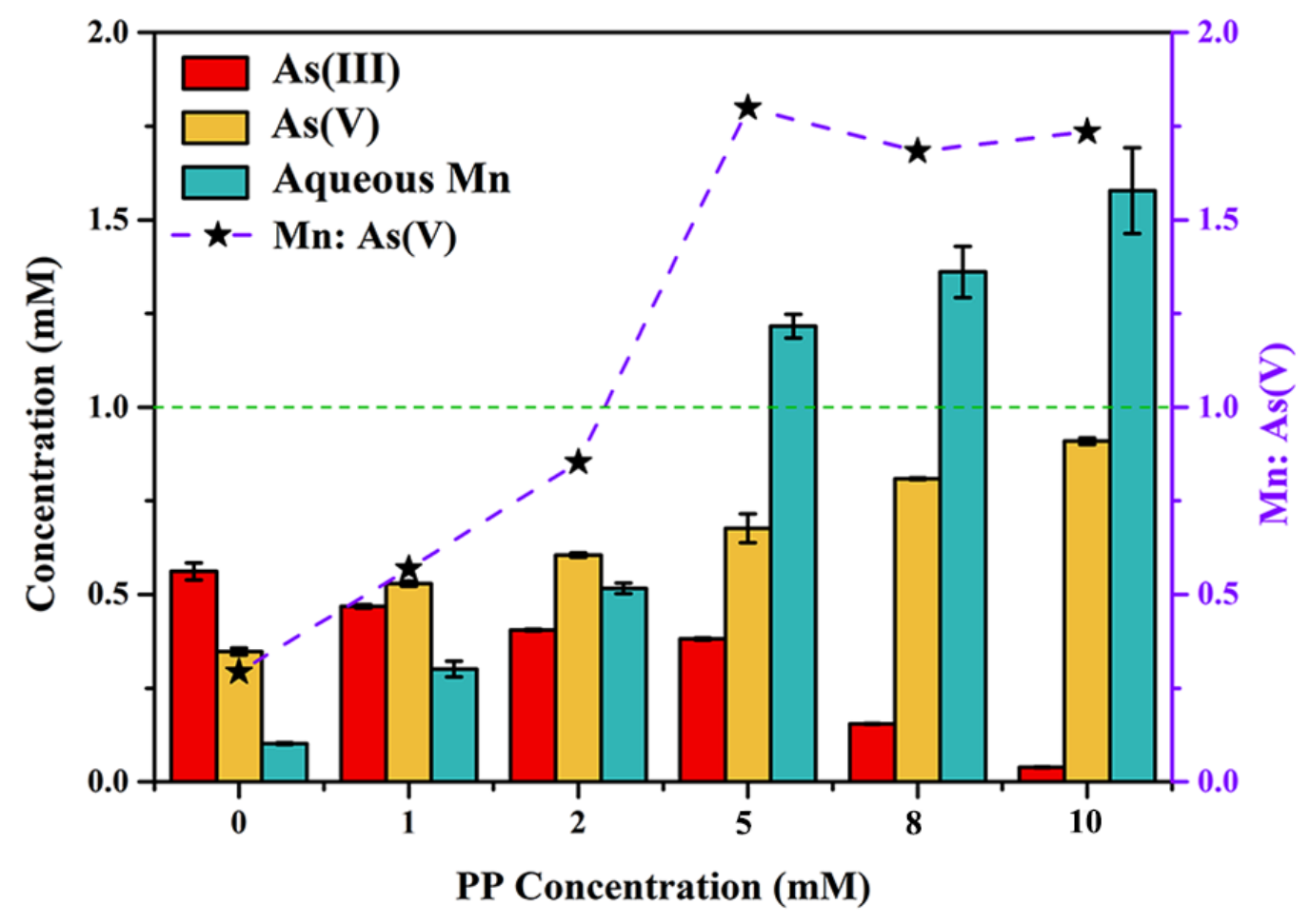

Fig. $3 \mathrm{As}(\mathrm{III}), \mathrm{As}(\mathrm{V})$, and $\mathrm{Mn}$ concentrations in solution and the ratio between $\mathrm{Mn}$ and $\mathrm{As}(\mathrm{V})$ as a function of the pyrophosphate $(\mathrm{PP})$ concentration for $\mathrm{As}(\mathrm{III})$ oxidation experiments in the presence of birnessite (1.0 mM initial As(III) concentration, initial $\mathrm{pH} 7.2,24 \mathrm{~h})$. 

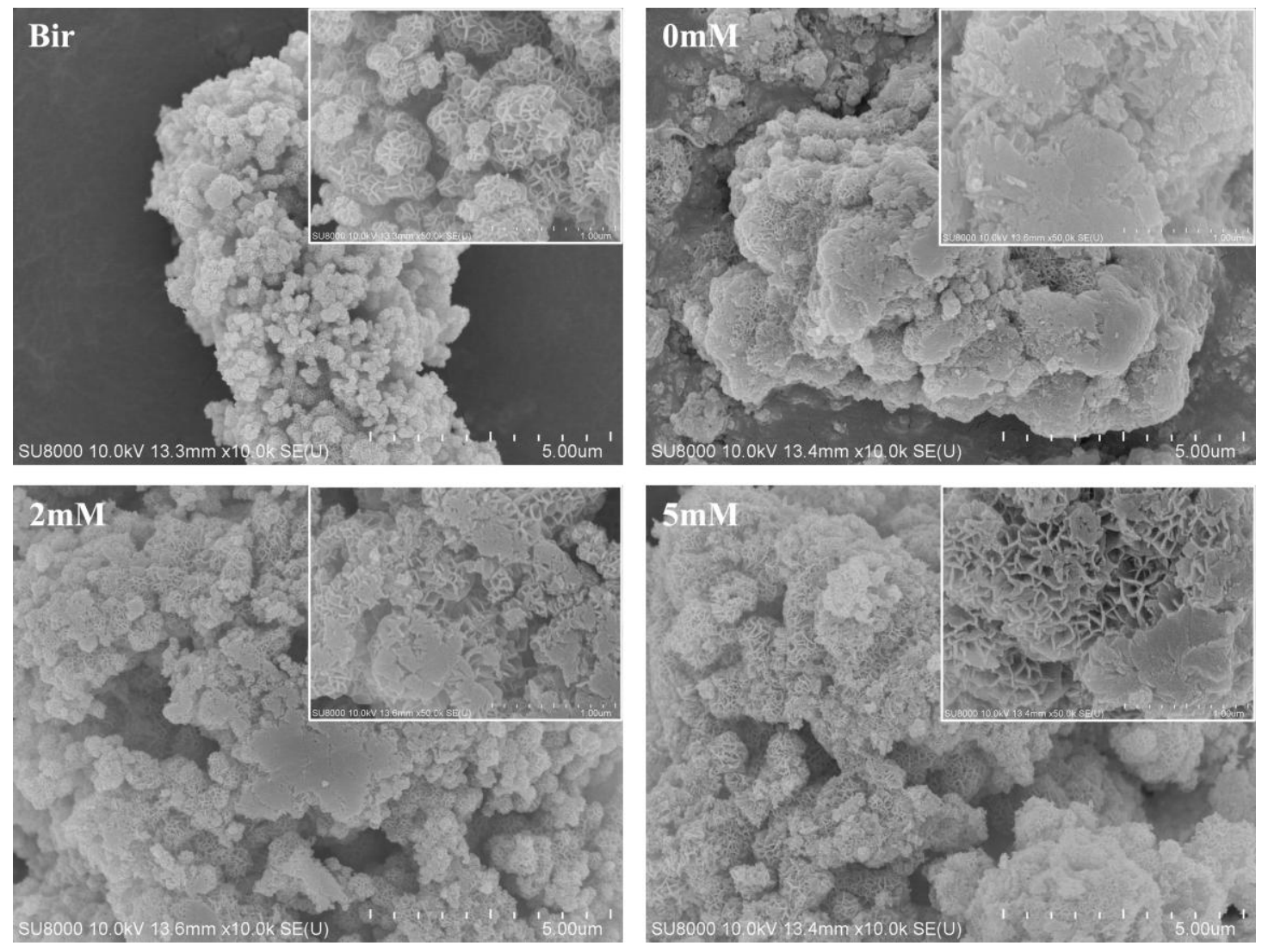

Fig. 4 FESEM images of unreacted synthetic birnessite (Bir) and of reaction products

from As(III) oxidation experiments in the presence of birnessite (1.0 mM initial As(III)

concentration, initial $\mathrm{pH} 7.2,24 \mathrm{~h})$. 0mM: absence of pyrophosphate (PP); 2mM:

initial PP concentration $2 \mathrm{mM}$; 5mM: initial PP concentration $5 \mathrm{mM}$. 

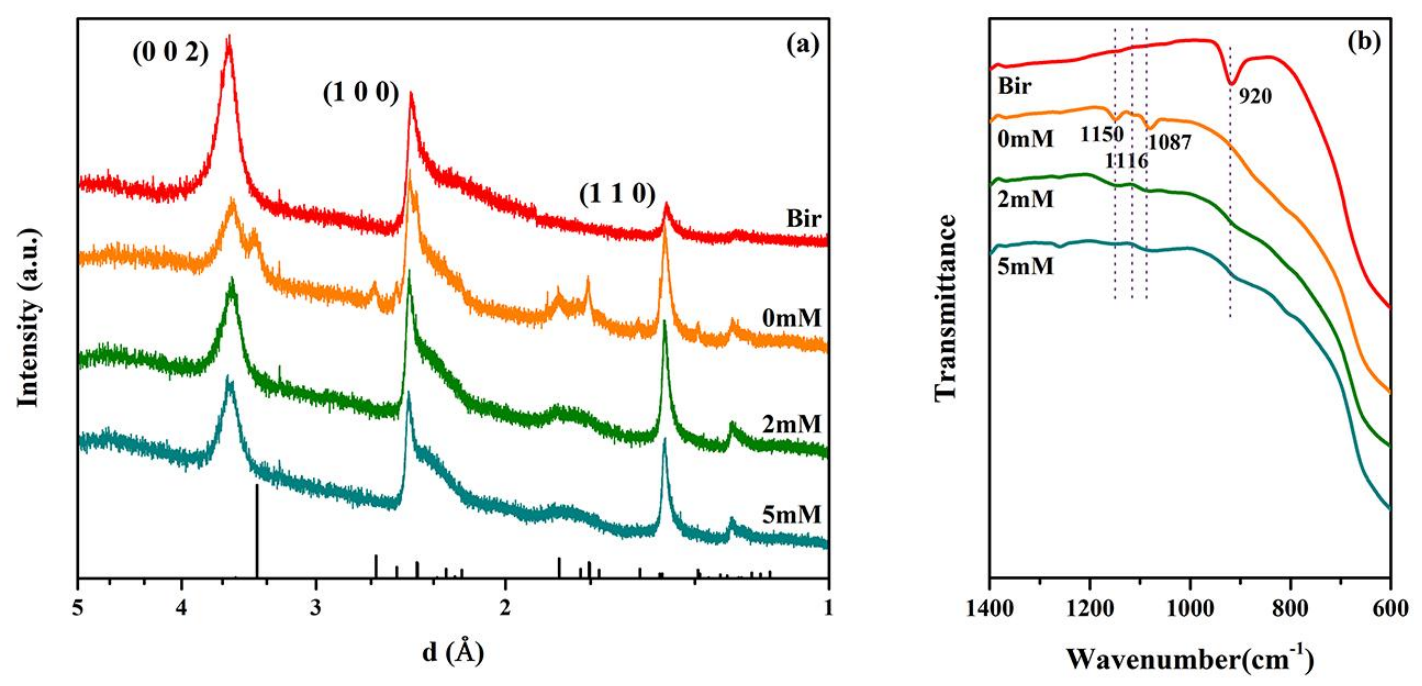

Fig. 5 (a) XRD patterns and (b) FT-IR spectra of unreacted birnessite (Bir) and of solid reaction products from As(III) oxidation experiments in the presence of birnessite (1.0 mM initial As(III) concentration, initial pH 7.2, $24 \mathrm{~h}$ ). 0mM, 2mM, and 5mM labels as in Fig. 4. Ticks at the bottom of (a) indicate the position of manganite reflections (ICDD\#41-1379). 

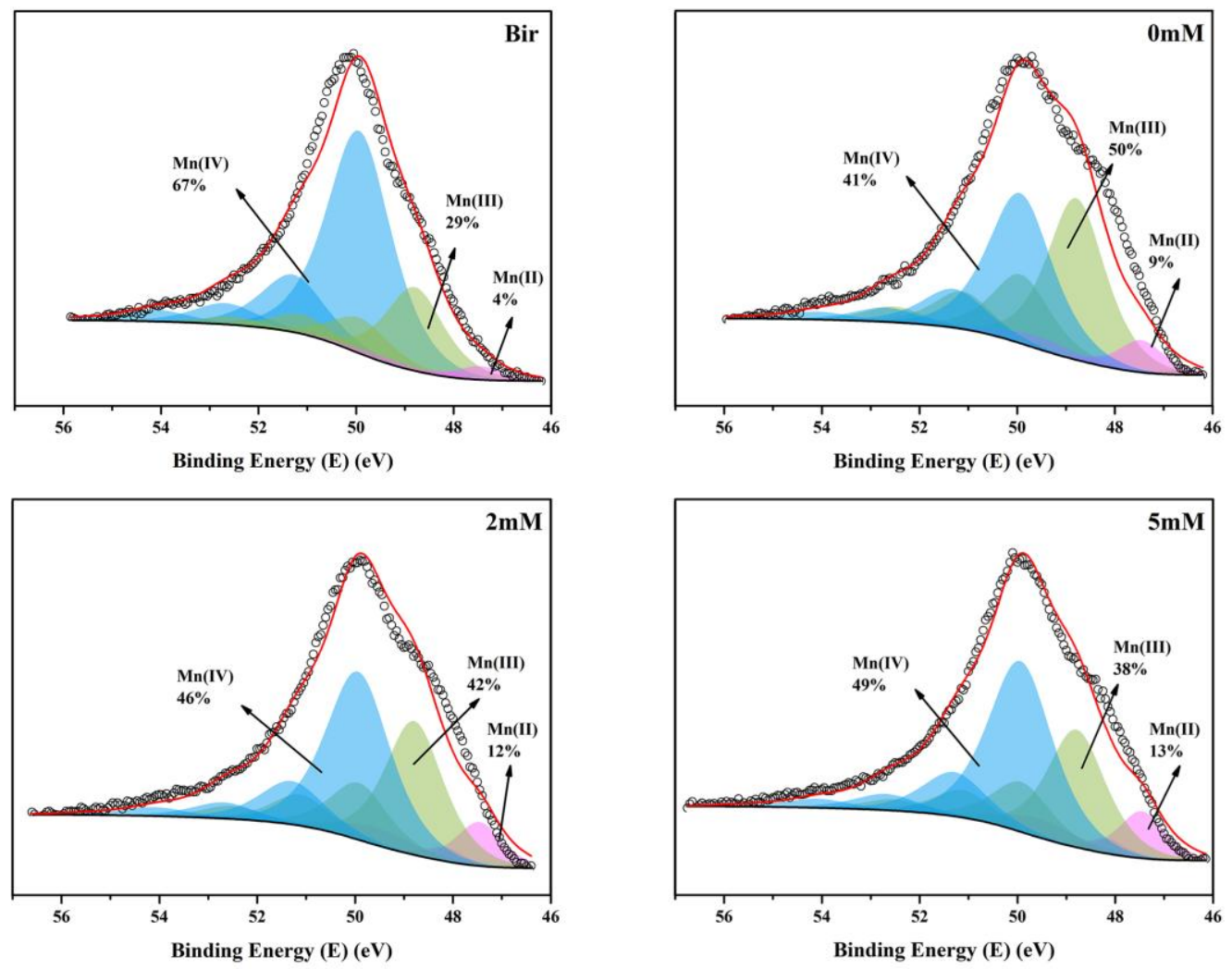

Fig. 6 XPS spectra (Mn3p) of unreacted birnessite (Bir) and of solid reaction products from As(III) oxidation experiments in the presence of birnessite (1.0 $\mathrm{mM}$ initial As(III) concentration, initial pH 7.2, 24 h). 0mM, 2mM, and 5mM labels as in Fig. 4. 

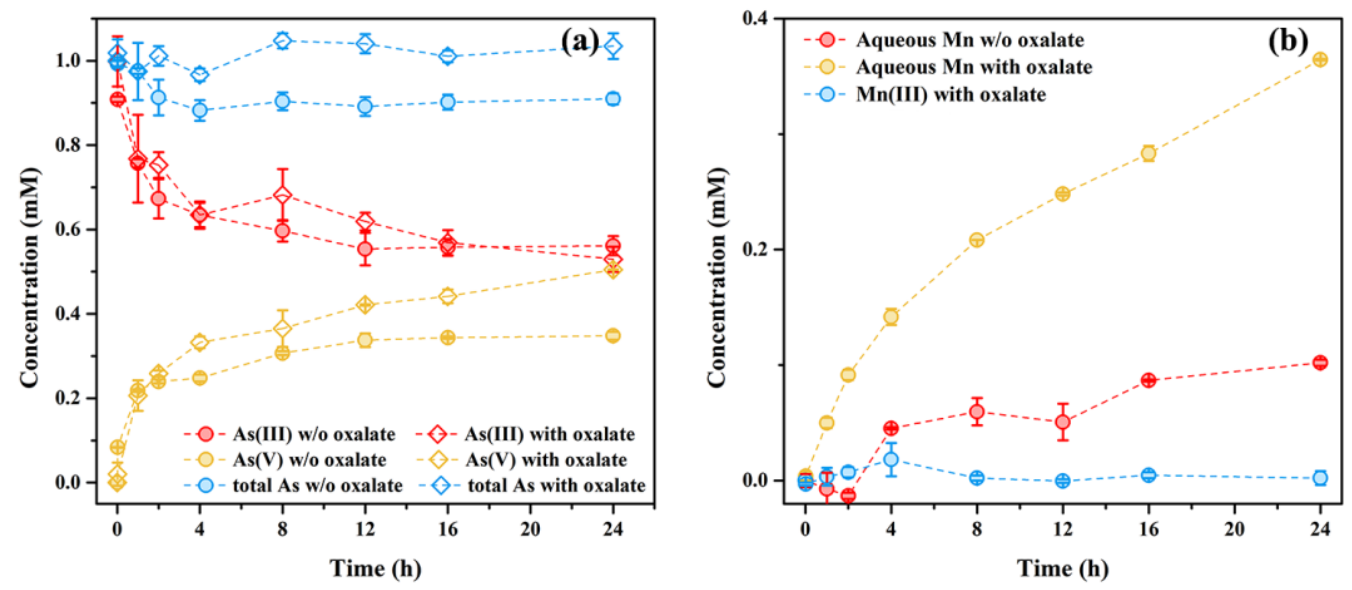

Fig. 7 Evolution of (a) As(III), As(V), and total As concentrations, and of (b) aqueous

$\mathrm{Mn}$ species concentrations during As(III) oxidation by birnessite in the absence/presence of $5 \mathrm{mM}$ oxalate $(1.0 \mathrm{mM}$ initial As(III) concentration, initial $\mathrm{pH}$ $7.2,24 \mathrm{~h})$. 
3 Highly enhanced oxidation of arsenite at the surface of birnessite in the presence

4 of pyrophosphate and the underlying reaction mechanisms

5

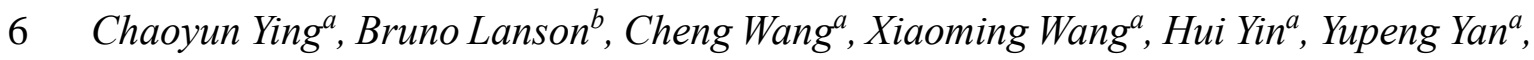

7 Wenfeng Tan $^{a}$, Fan Liu ${ }^{a}$, Xionghan Feng ${ }^{a, *}$

8

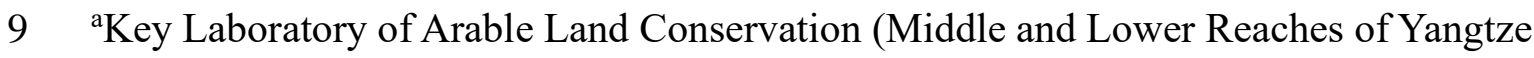

10 River), Ministry of Agriculture, College of Resources and Environment, Huazhong

11 Agricultural University, Wuhan 430070, China.

12 bUniv. Grenoble Alpes, CNRS, Univ. Savoie Mont Blanc, IRD, Univ. Gustave Eiffel,

13 ISTerre, F-38000 Grenoble, France

14

15

16

17

18 This PDF file includes:

19 Additional Materials \& Methods section

20 Supplementary Table S1 - S3

21 Supplementary Figures S1 - S8

22 References 


\section{In-situ quick As K-edge XANES spectroscopy.}

In-situ quick As K-edge X-ray Absorption Near Edge Structure (XANES) spectroscopy data were collected at $\sim 25{ }^{\circ} \mathrm{C}$ at the $1 \mathrm{~W} 2 \mathrm{~B}$ beamline of Beijing Synchrotron Radiation Facility in fluorescence mode, to track the evolution of As(III) and $\mathrm{As}(\mathrm{V})$ relative proportions during the oxidation of $2.0 \mathrm{mM} \mathrm{As}(\mathrm{III})$ in the presence of $1.6 \mathrm{~g} / \mathrm{L}$ birnessite and $5 \mathrm{mM}$ PP at $\mathrm{pH} \sim 7.5$. Experimental conditions were similar to those reported by Ginder-Vogel et al. (2009) and could be described as follows. The 50 $\mathrm{mL}$ suspensions were stirred in $100 \mathrm{~mL}$ plastic beakers with a small hole $(\varnothing=1 \mathrm{~cm})$ close to the bottom. The spectroscopy data were continuously collected as a function of reaction time between 11.67 and $12.46 \mathrm{keV}$. Elementary spectra were collected within $40 \mathrm{~s}$ each. The Athena program was used for background removal and linear combination fittings (LCF) for quantifying the speciation variations of As using As(III) and $\mathrm{As}(\mathrm{V})$ references.

(1)

(1)

9

0

1

(1)

3

4


49 Evolution as a function of time of the solution UV-Vis absorbance at $480 \mathrm{~nm}$ from

$50 \mathrm{As}(\mathrm{III})$ oxidation experiments in the presence of $\mathrm{Mn}(\mathrm{III})-\mathrm{PP}(0.5 \mathrm{mM}$ initial As(III)

51 concentration, initial pH 7.2). Blank experiments without As(III) were also conducted.

52

\begin{tabular}{|c|c|c|c|c|}
\hline \multirow{2}{*}{ Samples } & \multicolumn{2}{|c|}{$0.5 \mathrm{mM} \mathrm{Mn}(\mathrm{III})-\mathrm{PP}\left(\mathrm{Abs}_{480 \mathrm{~nm}}\right)$} & \multicolumn{2}{|c|}{$1 \mathrm{mM} \mathrm{Mn}(\mathrm{III})-\mathrm{PP}\left(\mathrm{Abs}_{480 \mathrm{~nm}}\right)$} \\
\hline & $0.5 \mathrm{mM} \mathrm{As}(\mathrm{III})$ & No As(III) & $0.5 \mathrm{mM} \mathrm{As}(\mathrm{III})$ & No As(III) \\
\hline $0 \mathrm{~h}$ & 0.0363 & 0.0368 & 0.0720 & 0.0684 \\
\hline $24 \mathrm{~h}$ & 0.0355 & 0.0372 & 0.0726 & 0.0690 \\
\hline
\end{tabular}

53

54

55

56

57

58

59

60

61

62

63

64

65 
67 Parameters used for fitting Mn3p XPS spectra of birnessite before and after As(III)

68 oxidation in the absence/presence of PP (from Ilton et al., 2016).

\begin{tabular}{ccc}
\hline & Binding Energy $(\mathrm{eV})$ & FWHM $(\mathrm{eV})$ \\
\hline Mn(II)3p Parameters & & \\
Mn(II) & 47.46 & 1.12 \\
Mn(II) & 48.16 & 0.93 \\
Mn(II) & 49.59 & 1.97 \\
Mn(III)3p Parameters & & \\
Mn(III) & 48.79 & 1.42 \\
Mn(III) & 49.92 & 1.42 \\
Mn(III) & 51.11 & 1.42 \\
Mn(III) & 52.52 & 1.42 \\
Mn(III) & 46.57 & 1.21 \\
$M n(I V) 3 p$ Parameters & & \\
Mn(IV) & 49.94 & 1.57 \\
Mn(IV) & 51.29 & 1.57 \\
$\operatorname{Mn}(\mathrm{IV})$ & 52.68 & 1.57 \\
$\operatorname{Mn}(\mathrm{IV})$ & 54.08 & 1.57 \\
$\operatorname{Mn}(\mathrm{IV})$ & 55.56 & 1.71 \\
\hline
\end{tabular}

69

70

71

72

73

74

75

76 
78 Parameters used for fitting As3d XPS spectra of birnessite before and after As(III)

79 oxidation in the absence/presence of PP (from Bang et al., 2005).

\begin{tabular}{ccc}
\hline & Binding Energy $(\mathrm{eV})$ & FWHM $(\mathrm{eV})$ \\
\hline As3 $d$ Parameters & & \\
As(III) & 44.20 & 1.39 \\
As(V) & 45.40 & 1.32 \\
\hline
\end{tabular}

80

81

82

83

84

85

86

87 


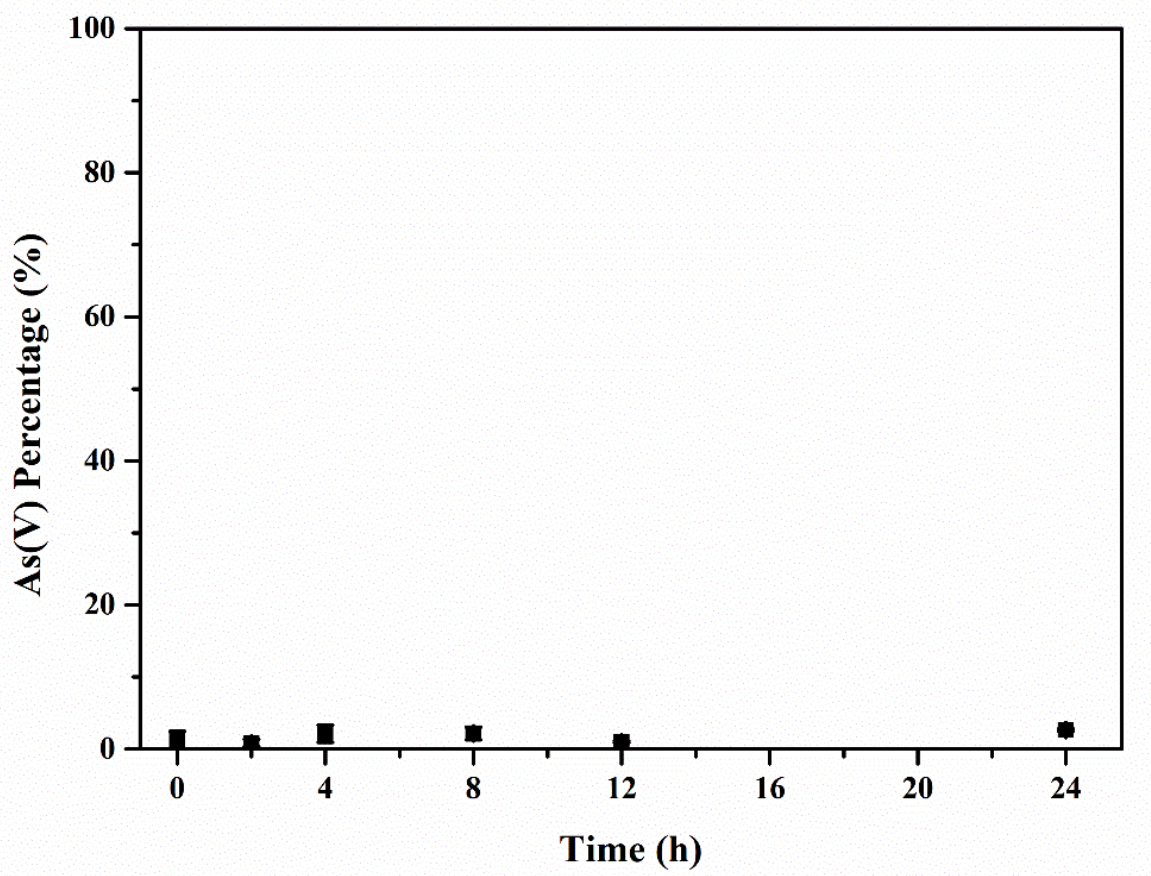

88

89 Fig. S1 Evolution of As(V) relative proportion during an As(III) oxidation experiment

90 in the absence of birnessite (0.5 mM initial As(III) concentration, initial $\mathrm{pH}$ 7.2).

91

92

93

94 


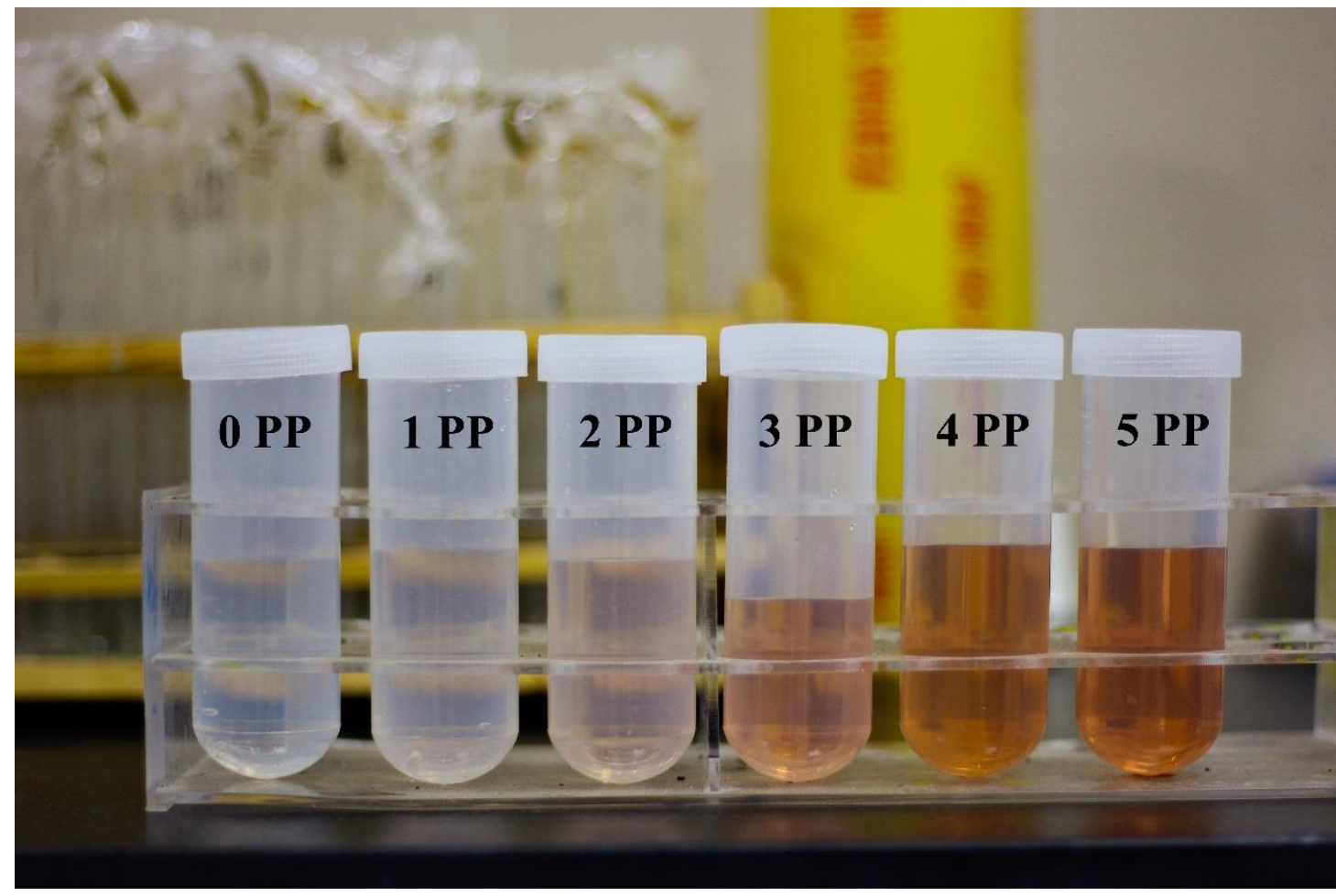

96 Fig. S2 Evolution of solution color from As(III) oxidation experiments performed in

97 the presence of birnessite with variable initial concentrations of PP $(0.5 \mathrm{mM}$ initial

98 As(III) concentration, initial pH 7.2, 24 h). 


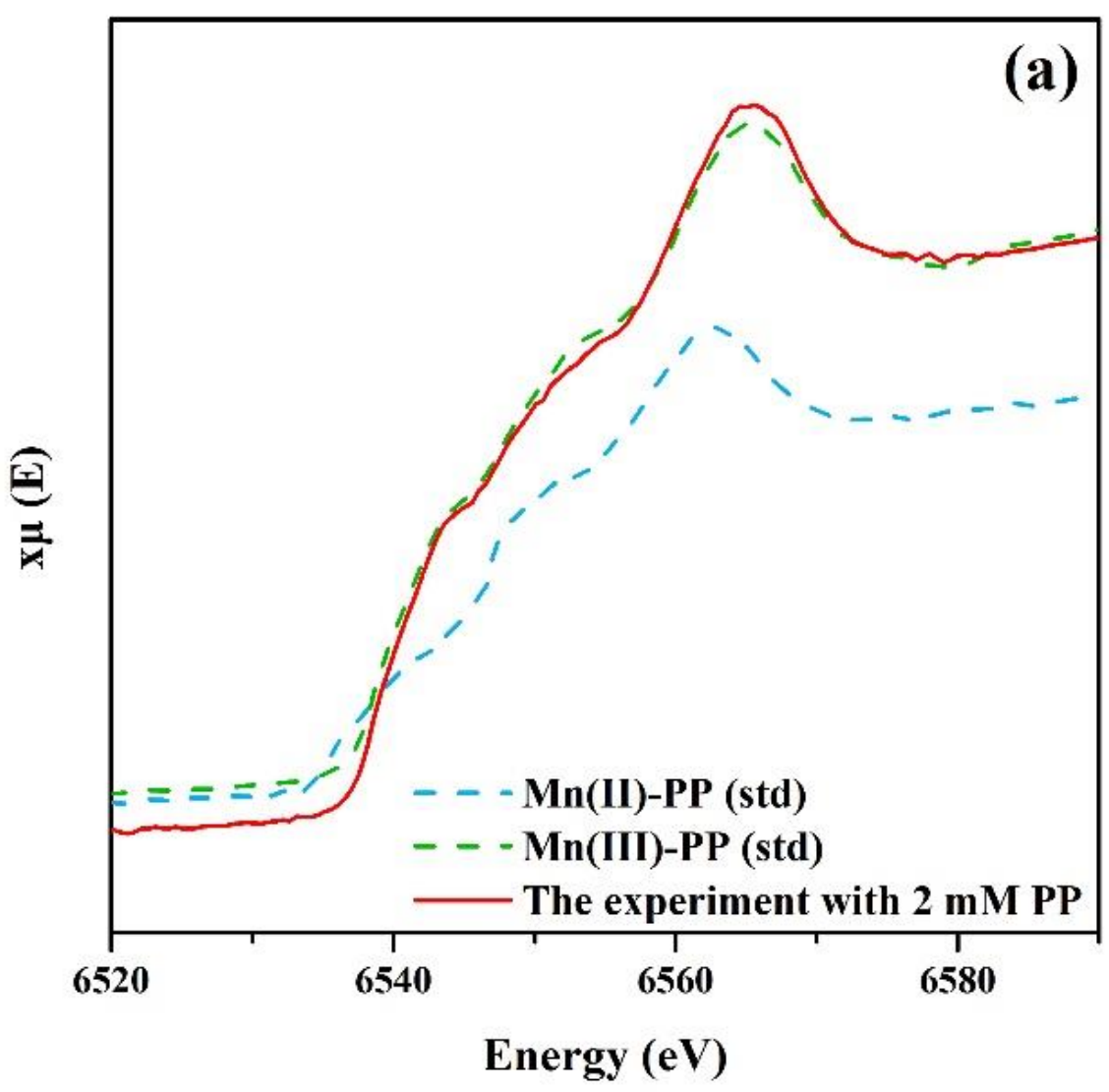

99

100 Fig. S3 Mn K-edge XANES spectrum of the solution resulting from an As(III)

101 oxidation experiment in the presence of birnessite (1.0 $\mathrm{mM}$ initial As(III) concentration,

$1022 \mathrm{mM}$ initial PP concentration, initial $\mathrm{pH} 7.2,24 \mathrm{~h}$ ) compared with $\mathrm{Mn}(\mathrm{II})-\mathrm{PP}$ and

$103 \mathrm{Mn}(\mathrm{III})-\mathrm{PP}$ reference spectra.

104

105 


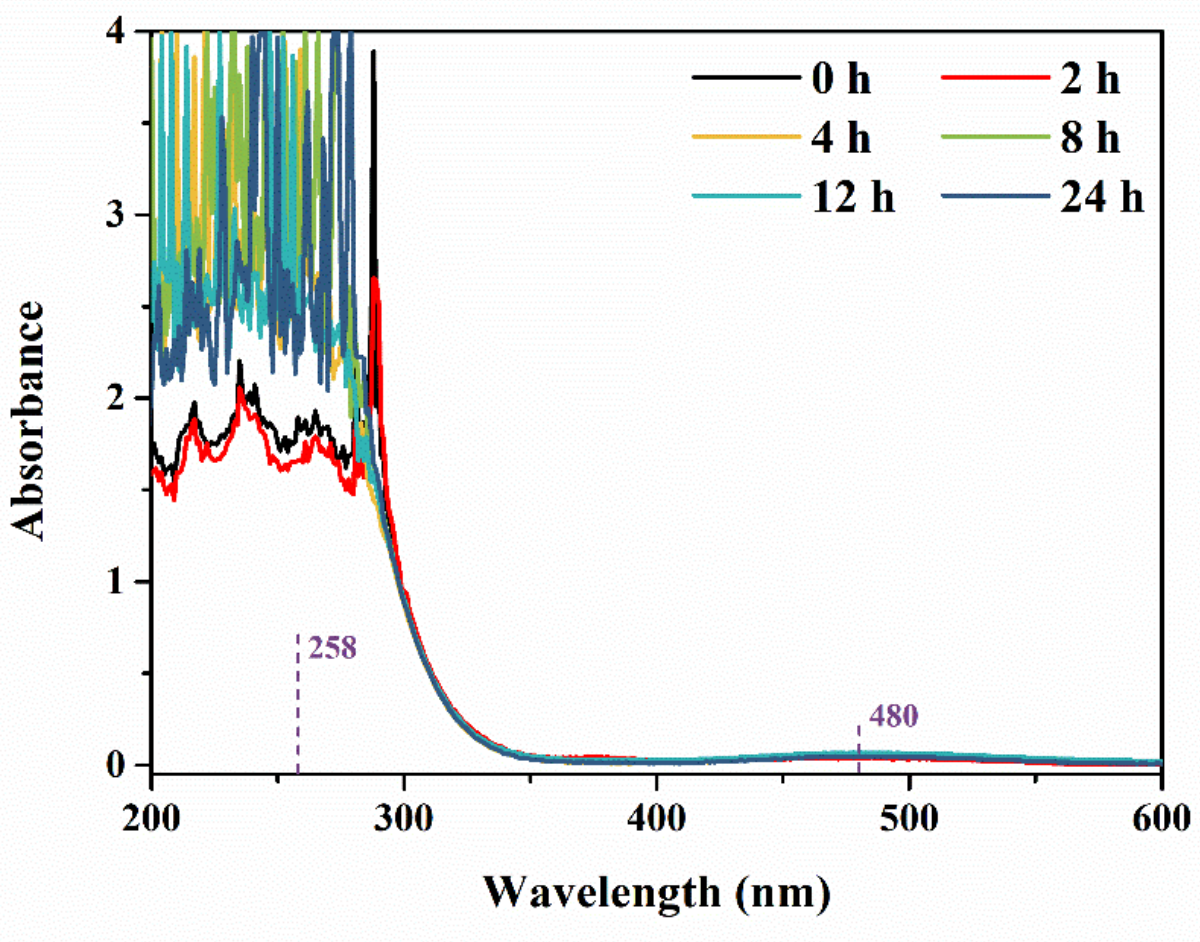

106

107 Fig. S4 Evolution as a function of time of UV-Vis absorption spectra of a solution 108 containing $0.5 \mathrm{mM} \mathrm{Mn(III)-PP}$ and $0.5 \mathrm{mM} \mathrm{As}(\mathrm{V})$ (initial pH 7.2, $24 \mathrm{~h}$ ).

109

110 


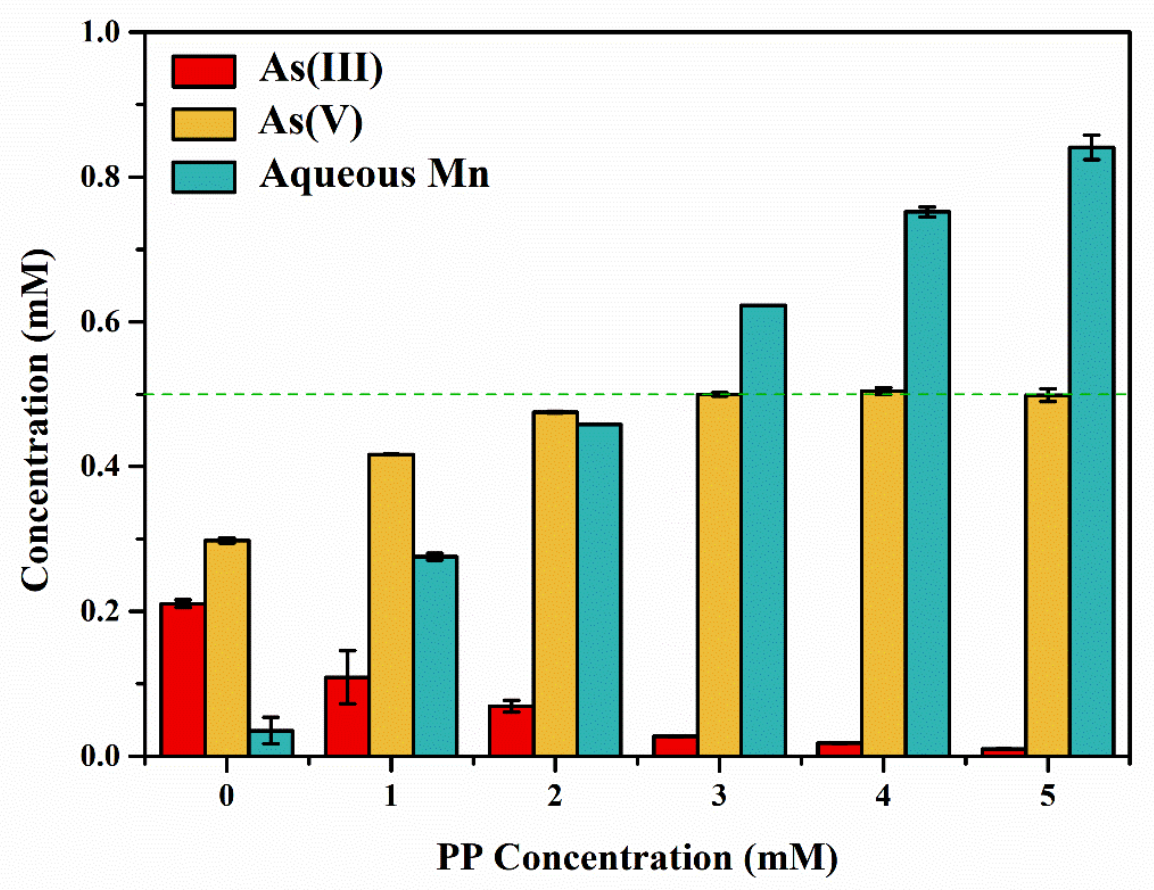

111

112 Fig. S5 As(III), As(V), and Mn concentrations in solution as a function of the

113 pyrophosphate (PP) concentration for As(III) oxidation experiments in the presence of

114 birnessite (0.5 mM initial As(III) concentration, initial pH 7.2, $24 \mathrm{~h})$.

115

116

117 

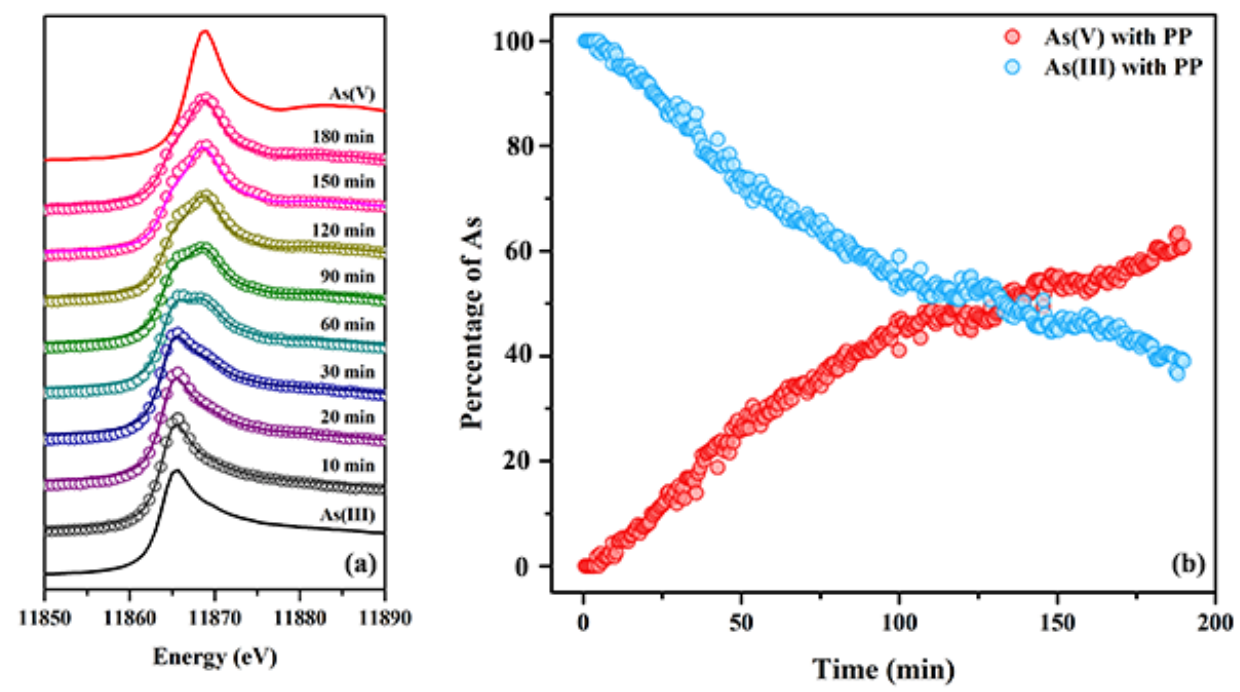

118

119 Fig. S6 (a) Selected As K-edge XAS spectra used to determine the relative proportions

120 of $\mathrm{As}(\mathrm{III})$ and $\mathrm{As}(\mathrm{V})$ during an $\mathrm{As}(\mathrm{III})$ oxidation experiment in the presence of

121 birnessite $(2.0 \mathrm{mM}$ initial $\mathrm{As}(\mathrm{III})$ concentration, $1.6 \mathrm{~g} / \mathrm{L}$ initial birnessite, $5 \mathrm{mM}$ PP

122 concentration, initial $\mathrm{pH}$ 7.5), (b) Evolution as a function of time of the relative

123 proportions of $\mathrm{As}(\mathrm{III})$ and $\mathrm{As}(\mathrm{V})$ determined from the linear combination fitting (LCF)

124 of the As K-edge XAS data shown in (a). 


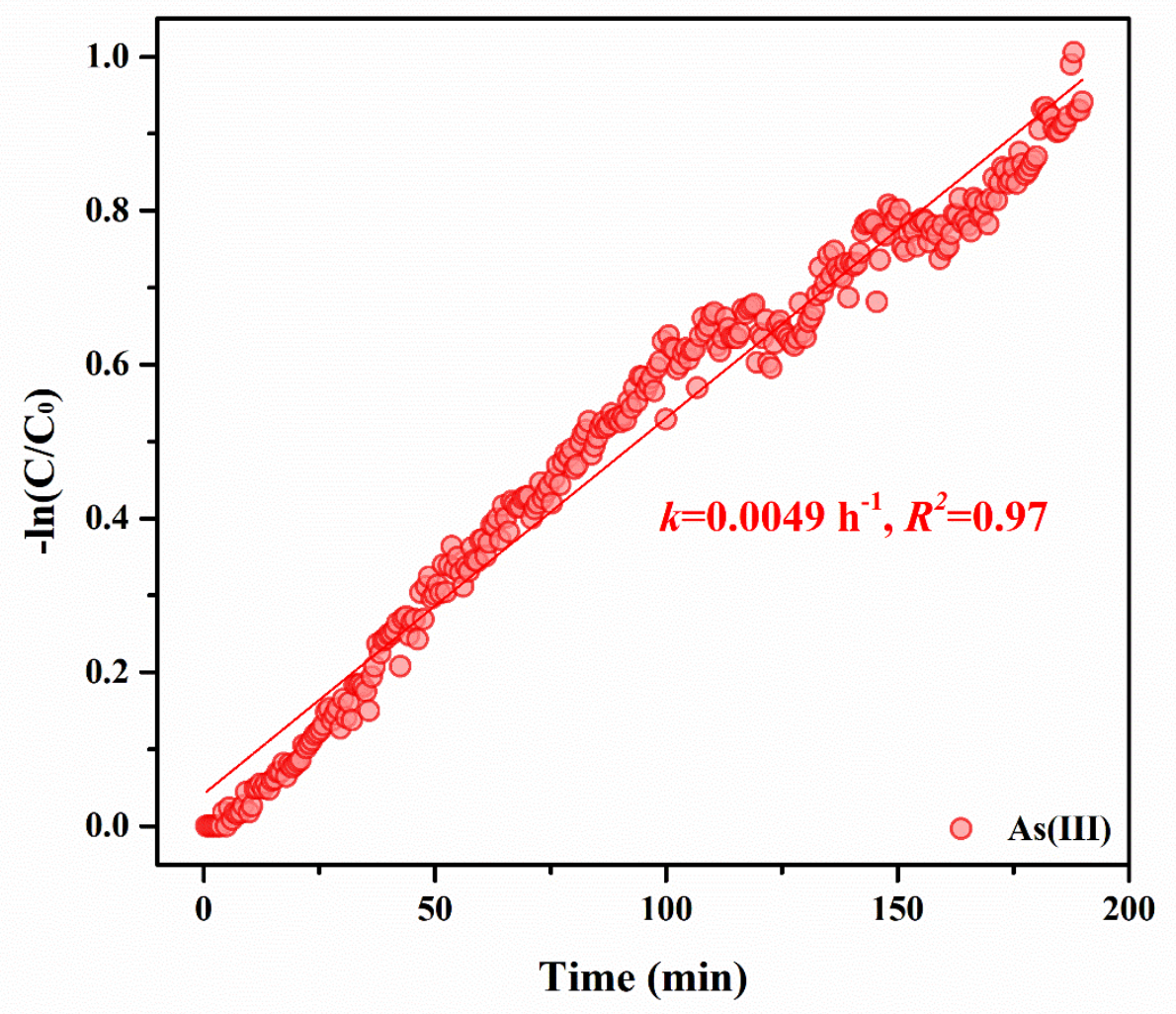

126

127 Fig. S7 Kinetic analysis of As(III) removal deduced from the linear combination fitting

128 (LCF) results of As K-edge XANES spectra shown in Fig. S6(b) using pseudo-first

129 order model (2.0 mM initial As(III) concentration, $1.6 \mathrm{~g} / \mathrm{L}$ initial birnessite, $5 \mathrm{mM}$ PP

130 concentration, initial $\mathrm{pH}$ 7.5).

131 


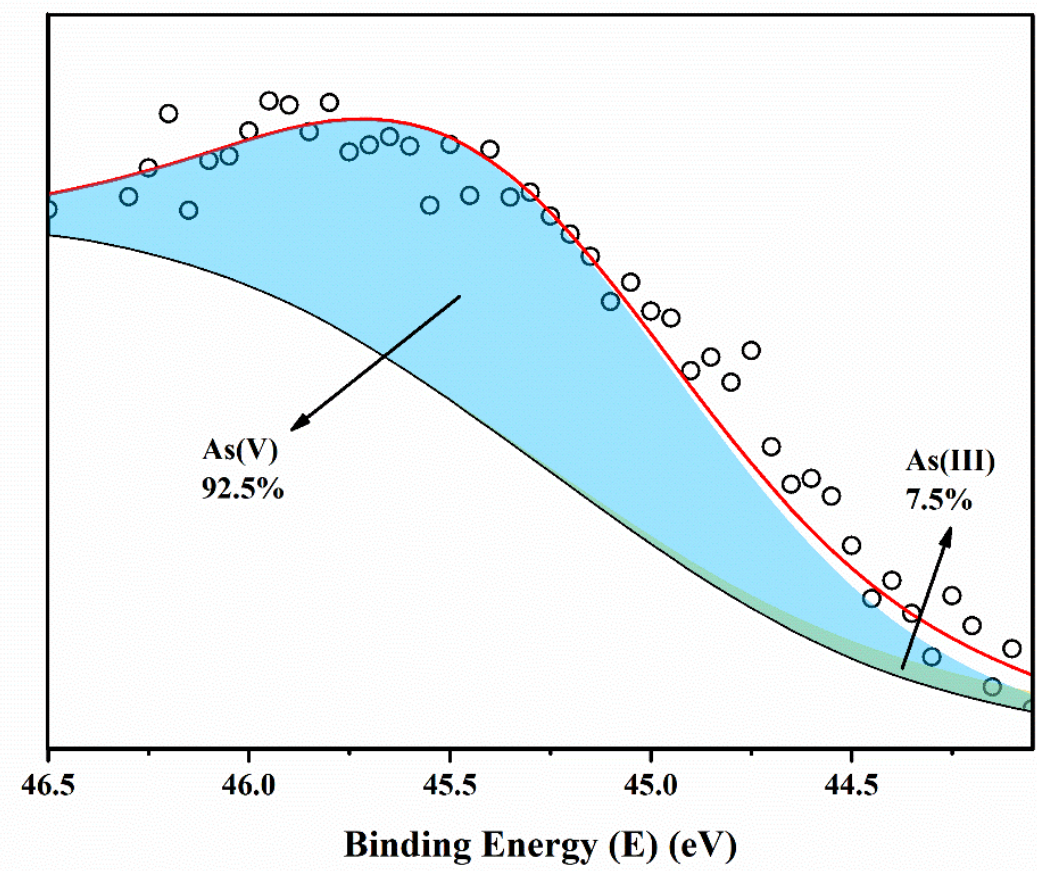

132

133 Fig. S8 As3d XPS spectrum of reaction products from an As(III) oxidation experiment

134 in the presence of birnessite and absence of PP (1.0 mM initial As(III) concentration,

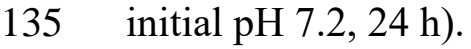

136

137

138

139

140

141

142

143 


\section{References}

145 Bang, S., Johnson, M.D., Korfiatis, G.P. and Meng, X. 2005. Chemical reactions between arsenic and 146 zero-valent iron in water. Water Res. 39(5), 763-770.

147 Ginder-Vogel, M., Landrot, G., Fischel, J.S. and Sparks, D.L. 2009. Quantification of rapid 148 environmental redox processes with quick-scanning X-ray absorption spectroscopy (Q-XAS). 149 Proc. Natl. Acad. Sci. U S A 106(38), 16124-16128.

150 Ilton, E.S., Post, J.E., Heaney, P.J., Ling, F.T. and Kerisit, S.N. 2016. XPS determination of Mn oxidation 151 states in Mn (hydr)oxides. Appl. Surf. Sci. 366, 475-485.

152 